\title{
7 \\ Prime Minister of an Occupied Nation: The Emperor System and the New Constitution
}

\section{The Formation of the Shidehara Cabinet}

\section{Accepting Defeat}

At noon on 15 August 1945, the Shōwa emperor's voice was directly broadcast to the nation via radio for the very first time. ${ }^{1}$ Known as the Jewel Voice Broadcast, this broadcast informed the citizens of Japan that the war had been lost. Today, this broadcast is seen as synonymous with the official end of the war. However, it should be remembered, first, that the formal, indirect language of the Jewel Voice Broadcast made it extremely difficult for ordinary Japanese people to understand what the emperor was saying. Many citizens only learned that the war was lost from the subsequent explanations in newspaper reports and on the radio. Second, the imperial edict was actually promulgated on 14 August, and the emperor's reading of it was also recorded on that day. Thus, the Jewel Voice Broadcast on 15 August was merely the occasion when that reading was broadcast to the public.

Preceding the Jewel Voice Broadcast was the 'imperial decision' of the Shōwa emperor. This imperial decision was handed down on two occasions. The first occasion was 10 August. It led to the Suzuki Kantarō 
cabinet contacting the Allies with word of their acceptance of the Potsdam Declaration (i.e. that Japan was offering its unconditional surrender). However, this offer was made based on the understanding that there would be no changes to Japan's sovereignty and the supreme authority of the emperor. Secretary of State Byrnes responded in a somewhat elusive manner to this request. The second imperial decision was handed down on 14 August. This confirmed the acceptance of the Potsdam Declaration. On that same day, the official imperial edict declaring an end to the war was promulgated. The command to cease hostilities was given on 16 August. On the following day, the Suzuki cabinet was replaced by a new cabinet headed by Prince Higashikuni.

On 2 September, on the deck of the USS Missouri, Foreign Minister Shigemitsu Mamoru and Chief of Army General Staff Umezu Yoshijirō signed the terms of surrender. It is said that the ministers of the Higashikuni cabinet 'had extremely pained expressions' when learning that the word 'surrender' appeared in the document. ${ }^{2}$ As noted above, the foreign minister in Prince Higashikuni's cabinet was Shigemitsu Mamoru. He would later be replaced with Yoshida Shigeru. As it happened, the Higashikuni cabinet was extremely short-lived. Its members resigned at the beginning of October. Such a cabinet, led by a member of the imperial household, was formed in order to suppress any resistance to surrender from the military. It could not remain in office because the General Headquarters of the Supreme Commander for the Allied Powers (GHQ) demanded far more political democratisation than was expected.

The following cabinet was the Shidehara cabinet. Shidehara asked Yoshida Shigeru to continue as foreign minister. In the immediate aftermath of the war, Shidehara, Yoshida and the other leaders of the nation faced four urgent political tasks. First, there was the issue of how to deal with the defeat itself. This was basically the problem of who was responsible for the war. Second, there was the issue of what would happen to the Shōwa emperor. Although the emperor was understood to have brought about peace by issuing an 'imperial decision', the very issuing of an 'imperial decision' connected him to the problem of who was responsible for the war in the first place. Third, there was the matter of reforming the constitution. Finally, there was the reconstruction of party politics.

Shidehara was deeply involved in each of these tasks. Although he had once helped lay the foundations for an age with his work as foreign minister, he had been practically forgotten during the war years. 
Now, in the unprecedented circumstances of an occupied Japan, he would once again be pushed into political life. Following the resignation of the Higashikuni cabinet, Shidehara became the prime minister of Japan in the early period of occupation. How did Shidehara deal with questions that arose in the aftermath of Japan's defeat? Further, what role did he have to play in the construction of the postwar political system?

In this chapter I shall seek to shed light on these topics. Beginning with the formation of the Shidehara cabinet, I will proceed to examine Shidehara's involvement in the Investigation Committee for the Greater East Asia War, his relationship with the Showwa emperor, his contribution to the creation of a new constitution and his participation in party politics. ${ }^{3}$

\section{Forming the Cabinet}

On the morning of 15 August 1945, Shidehara departed for a social gathering at the Japan Club. It was there that he would hear the Jewel Voice Broadcast. 'The unconditional surrender of the imperial army was of the greatest regret. Upon hearing the emperor's voice announcing the imperial rescript on the radio, my tears flowed quite involuntarily.' Shidehara found he could hardly remain at the club following such momentous news. Instead, under the blazing sun, he hurried home, and there he stayed. Shidehara wrote a letter to his close friend Ōdaira Komatsuchi, former vice-president of the South Manchuria Railway Company. With 'the whole country banding firmly together', Shidehara wrote, 'I believe that within a short time, we may enhance the glory of the nation to a point beyond that of the prewar era. ${ }^{4}$

For Shidehara, Japan's defeat did not necessarily mean a complete loss of confidence. He saw that it could actually be an opportunity for rebirth. Indeed, this was certainly the case for Shidehara personally. Japan's prime minister during the period of occupation could not be somebody who was at risk of being accused of complicity in the war. As he had once been so active on the world stage, Shidehara quickly rose to the top of the potential candidates for the role. In truth, had the Pacific War not broken out, he would have been forgotten as simply a diplomat who had been unpopular with the citizenry. Yet the war, and Japan's eventual defeat, would instead offer him an abrupt reversal of fortunes. 
Directly after the end of the war, Shidehara wrote a paper titled 'Shūsen Zengosaku' (Postwar remedial measures). In it, Shidehara recommended that Japan work to build relationships of trust with the Allied nations. It would need to remember its defeat yet look towards the future. With effort, Japan could secure an advantageous position in the international order. To this end, it was also important that the government properly investigate the causes of the defeat and make its findings public. Shidehara proceeded to offer four reasons for why Japan had lost the war: the conflation of state affairs and supreme command, insufficient research in the natural sciences, the termination of military production due to air raids and the destructive force of the atomic bombs. Shidehara would provide a copy of 'Shūsen Zengosaku' to Foreign Minister Yoshida in the Higashikuni cabinet in October 1945.

It might be asked, however, why Shidehara prepared this paper. In fact, we know that by the end of the Pacific War, government figures such as former home affairs officials Tsugita Daisaburō and Nagaoka Ryūichirō had already asked Shidehara to put himself forward as a candidate for prime minister. Shidehara's writing of 'Shūsen Zengosaku' was not unrelated to his possible return to politics. ${ }^{6}$ Shidehara knew it was possible that he might become the next leader of Japan.

Lord Keeper of the Privy Seal Kido Köichi had raised the possibility of Foreign Minister Yoshida succeeding Prince Higashikuni as prime minister. However, Yoshida thought Shidehara was more appropriate for the job. To discuss the matter further, Kido met with Prince Higashikuni, Konoe Fumimaro and Chairman of the Privy Council Hiranuma Kiichirō. They concluded that Shidehara was the top candidate, followed by Yoshida. Their criteria were that the candidate needed to be 'somebody without ill feelings towards the US, who was free of any doubt as to their responsibility for the war, and who was well versed in matters of diplomacy'. ${ }^{7}$ When Yoshida thereafter obtained the informal agreement of Douglas MacArthur, the Supreme Commander for the Allied Powers, Yoshida asked Shidehara to be appointed as prime minister. However, Shidehara himself was not easily persuaded to accept this responsibility.

On 6 October, Shidehara had an audience with the Shōwa emperor. When the emperor sought to draw Shidehara out on the topic of becoming prime minister, he refused to accept the implicit offer, saying, 'I do not believe I am capable'. ${ }^{8}$ Shidehara was already 73 years old and had spent 
10 years in political opposition. Further, even when serving as a diplomat, he had sought to keep his distance from domestic politics. Yet, Shidehara recollects, he then:

Observed just how much [this answer] pained [the emperor]. Things had already gotten to this stage, so [I] could hardly bear to cause the emperor further worry. I therefore swore to myself that I would do whatever I could, even at the cost of my own life. Then I responded: ' $\mathrm{I}]$ am lacking in confidence that I can handle this important responsibility. However, let me do everything in my power to honor your will.' I then withdrew from his presence. ${ }^{9}$

Although Shidehara may not have been filled with confidence, it should be remembered that only less than two months had gone by since the war ended in ruinous defeat. Surely there was not a soul who could have confidently assumed responsibility for the nation in such circumstances. The emperor also understood this. After all, even Yoshida, who was known for his daring, hesitated to agree to become prime minister during such unprecedented difficulties. Shidehara fortified his will and eventually issued his reply to the throne: 'I will devote all of my strength to do what is necessary'. ${ }^{10}$ Ultimately, Kido's cooperation with the emperor ensured that Shidehara was unable to decline the offer. Kido himself believed that 'there was nobody else we could turn to ... it is best if we have the emperor himself thoroughly bring him around'. ${ }^{11}$ The key cabinet ministers were thus selected: Shidehara, Yoshida and Tsugita. Yoshida remained foreign minister, while Tsugita became the chief cabinet secretary.

On 9 October, the Shidehara cabinet was at last officially sworn in. As newspaper reporters surrounded Shidehara, one blurted out: 'So, Mr. Shidehara, it turns out you were still alive, huh?' ${ }^{12}$ It is also worth pointing out that to this day, Shidehara and Suzuki Kantarō remain the only prime ministers of Japan who were originally from Osaka.

Given Shidehara's background, it would not have been unnatural for the positions in his cabinet to be filled with individuals affiliated with the old Minseitō party. And, indeed, there were Minseitō-affiliated ministers in the cabinet beyond Tsugita. For example, there was the agriculture minister, Matsumura Kenzō; the transport minister, Tanaka Takeo; and the minister for commerce and industry, Ogasawara Sankurō. However, Ashida Hitoshi, the health and welfare minister, was originally a member of the old Seiyūkai party. Yoshida Shigeru, who continued as foreign minister under Shidehara, had also once served as vice-minister for foreign 
affairs in the Seiyūkai party cabinet of Tanaka Giichi. From Shidehara's perspective, Yoshida was more of a collateral than a mainstream member of the Ministry of Foreign Affairs. Nevertheless, during his time in political opposition, Shidehara had strengthened his relationship with Yoshida.

While Home Minister Horikiri Zenjirō was once an official at the Ministry of Home Affairs, he did not have strong party affiliations. With Shidehara's permission, he proceeded to work on revising the electoral laws, a task that included the incorporation of women's suffrage. Meanwhile, the chief of the Cabinet Legislation Bureau, Narahashi Wataru, was an international lawyer who had studied in France. Minister of State Matsumoto Jōji was a scholar of commercial law but had previously served as the minister of commerce and industry in the Saitō Makoto cabinet. Finance Minister Shibusawa Keizo had been the governor of the Bank of Japan. Justice Minister Iwata Chūzō and Education Minister Maeda Tamon remained in their positions from the earlier Higashikuni cabinet. ${ }^{13}$ Meanwhile, War Minister Shimomura Sadamu and Navy Minister Yonai Mitsumasa remained in their posts at the request of the emperor.

In a letter to Makino, Yoshida wrote that 'the staffing of the cabinet has generally been going smoothly'. ${ }^{14}$ Certainly, this was a cabinet staffed primarily on the basis of ability. Former Ministry of Home Affairs official Izawa Takio also used his behind the scenes influence to assist with the selection of cabinet personnel. As mentioned earlier, Shidehara and Izawa had been classmates at the Osaka Third Higher Middle School. However, Tsugita, Matsumura, Tanaka, Horikiri and Maeda were eventually forced out of the cabinet when they were purged from public office.

\section{Meeting with MacArthur: 'Japanese-Style Democracy'}

As soon as Shidehara became prime minister, the GHQ commissioned a report on him for their own purposes. The beginning of this report features a quote from former ambassador Grew's published diary, Ten Years in Japan. There were also references to a book by Moore, a former Ministry of Foreign Affairs adviser, titled With Japan's Leaders. The GHQ report referred to Shidehara as 'one of the old school of Japanese diplomats, a man of integrity as well as caution'. The report also contains some details from an interrogation of Tokuda Kyūichi, 
the leader of Japan's Communist Party. Tokuda had stated: 'Because of his weak nature, SHIDEHARA has the tendency to yield to any strong demand of the zaibatsu or even the military clique'. ${ }^{15}$

Viewed from another perspective, there was little information here that was of significance for the occupying army. Even MacArthur, upon hearing that Shidehara had been informally picked for prime minister, reportedly remarked to Foreign Minister Yoshida: 'Damn, he's old ... Can he speak English?' Yoshida, who had himself put Shidehara forward as a candidate, lamented this sorry state of affairs: 'Here is Mr. Shidehara, a master of English, as anybody who knows him would attest, and yet the general thinks it necessary to even ask, "Can he speak English?"'16 In Washington, President Truman was also struggling to size up Shidehara. He had to turn to former ambassador Forbes to get a sense of this man. Forbes told Truman that he regarded Shidehara to be 'a close personal friend of mine' and that he 'had the highest opinion of him'. Truman responded by saying that he was 'extremely glad to know that'. ${ }^{17}$ Although Forbes's relationship with Shidehara had been strained by the Manchurian Incident, Forbes had not forgotten him.

As the new prime minister of Japan, Shidehara faced the vital task of building a relationship with MacArthur. Just after the new cabinet was formed on 11 October, Shidehara visited the general. MacArthur had no time for pleasantries and sought to get down to business immediately. He asked Shidehara to carry out five reforms, now known in Japanese as the Five Great Reforms: women's suffrage, the encouragement of labour unions, liberal-style education, the abolition of secret trials and the democratisation of the economic system.

To these requests for democratisation, Shidehara responded without hesitation. He noted that the cabinet had already begun work on matters such as women's suffrage and that, as Japan already had 'democratic trends' before the war, it would not be difficult to move in that direction once again. Shidehara asserted that what Japan required was not US-style democracy but rather 'the development of a Japanese-style "democracy" more suitable to the nation's own circumstances. 'Quite so', responded MacArthur. ${ }^{18}$ This suggests that Shidehara had a positive impression of MacArthur, believing that he would be easy to deal with. From Shidehara's perspective, meanwhile, MacArthur's requests were already incorporated into the policy planning of his cabinet. There was, however, a pitfall to this way of thinking: Shidehara lacked sufficient awareness of GHQ's 
request for constitutional revision. In other words, MacArthur saw a new constitution as a prerequisite for his desired reforms. On the other hand, Shidehara had not acknowledged that a radical revision of the constitution was essential.

Although the Shidehara cabinet met on 12 October and discussed MacArthur's requested Five Great Reforms, Shidehara still did not seriously consider constitutional revision. ${ }^{19}$ Of course, it is worth pointing out that these were the early days of Japan's occupation, and innumerable tasks faced the country.

What, then, was the basic policy direction pursued by the Shidehara cabinet? Shidehara gave a speech on his administrative policy before the House of Representatives on 28 November. In this speech, Shidehara listed a number of specific policies to be pursued. Beginning with the revision of the electoral law, these policies addressed issues such as educational reform, freedom of expression, stability of the lives of the citizens, farmland reform, support for demobilised soldiers, restoration of regions damaged by war, improvement of land and sea transportation, and an investigation into the causes of the defeat. ${ }^{20}$ Of these, the investigation of the defeat would link directly to questions of who was responsible for the war to begin with. It also had the potential to touch upon the emperor system itself. Thus, this task required both prudence and speed.

\section{The Survey Association of Greater East Asia War}

At this time, the Ministry of Foreign Affairs was discreetly establishing a board for researching problems relating to the peace conditions. The aim was to conduct preliminary research on the implications of the signing of the peace treaty. The chief secretary of the board was Sugihara Arata, director-general of the Treaties and Conventions Bureau, while secretaries were selected from among the director-ranked staff of the various bureaus. ${ }^{21}$

That said, the finalisation of the peace process was still a long way off. The first challenge that the Shidehara cabinet faced was what lessons to take away from the defeat, and what changes would need to be made in the way the nation was run. One particularly difficult topic was that of responsibility for the war. On 30 October 1945, the Shidehara cabinet 
decided to create a new survey association specifically for the purpose of investigating the causes of the defeat. Towards the end of November, the government proclaimed the establishment of the Dai Tōa Sensō Chōsa-kai (Survey Association of Greater East Asia War). ${ }^{22}$

Aoki Tokuzō was selected as the secretary-general of the association. Chief Cabinet Secretary Tsugita had sounded out Aoki on assuming this position. Previously, Aoki had served as a Ministry of Finance official affiliated with the old Minseito party. The more difficult problem was who to appoint as president. Through Yoshida, Shidehara asked Makino Nobuaki if he would accept the responsibility. However, Makino firmly declined. Shidehara then sought out former prime minister Wakatsuki Reijirō. However, Wakatsuki also refused. In January 1946, the Dai Tōa Sensō Chōsa-kai was renamed the Sensō Chōsa-kai (War Research Institute). Even by this time, no one willing to act as president had been found. In the end, Shidehara had to take on the role himself. The institute's first general meeting was held on 27 March.

To start the meeting, Shidehara gave an address in his role as committee president, stating: 'The purpose of this institute is to clarify the causes behind, and facts relating to, the defeat in the war'. He added: 'Our mission is not that of investigating war criminals and holding them to account'. ${ }^{23}$ Shidehara also emphasised the significance of Article 9 contained in the draft for the new constitution. Aoki, who had written the original outline for Shidehara's address, noted that 'Mr. Shidehara had completely reworded what I had written'. ${ }^{24}$ There were 20 members of the Sensō Chōsa-kai, including the president of the Yomiuri Newspaper Company, Baba Tsunego. There were a further 18 provisional members of vice-ministerial level from the various government ministries. The Sensō Chōsa-kai consisted of a total of five subcommittees. The first of these was tasked with inquiring into political and diplomatic matters. The other four subcommittees were charged with considering the respective topics of military affairs, finance and economy, ideology, and science and technology.

The committee's second general meeting was held on 4 April 1946. Shidehara served as the chairman. On this occasion, Shidehara also stated that the 'problem of wartime responsibility' was not 'the main object of this institute'. On the contrary, Shidehara hoped that an inquiry into the facts and their relations, and the relaying of these details to the broader public, could 'help bring about an end to the fantasies that some individuals held about wars of this nature'. ${ }^{25}$ 
However, at this point, unexpected interference emerged. In a July meeting of the Allied Council for Japan, the Soviet Union criticised the Sensō Chōsa-kai for its inclusion of former military personnel. The Allied Council for Japan was an advisory body to the Supreme Commander for the Allied Powers, which had been established in Tokyo. The need for such an advisory body had been agreed upon in November of the previous year, during a foreign ministers' conference in Moscow. Although Shidehara objected to the Soviets' denunciation, the institute was abolished at the end of September 1946. ${ }^{26}$

These developments have been criticised for trivialising the pursuit of wartime responsibility. ${ }^{27}$ Certainly, the investigation of who had responsibility for the war may well have been insufficient. Nevertheless, Shidehara had an uncommonly strong will, as demonstrated in the following correspondence that Shidehara had sent to Makino:

The work of the Dai Tōa Sensō Chōsa-kai will serve to provide lessons of the greatest importance for ages to come, to ensure that the citizens of our nation do not repeat the mistakes of the past. This is why, as a matter of the greatest importance, I have disturbed you in particular with respect to the role of president of this committee, and why I earnestly await your instruction as to the general policies the committee should adopt. ${ }^{28}$

In other words, Shidehara, through Yoshida, had urged Makino to reconsider his refusal to accept the position of president. Shidehara also did not simply look on as the Sensō Chōsa-kai was abolished. Even after Shidehara left the office of prime minister on 22 April, he continued to show passion for preparing Japan for the future by thoroughly assessing the events of the past. Later, on 30 May, during the Yoshida cabinet, Shidehara met with Ashida and asked that he take on the role of vicepresident of the Sensō Chōsa-kai before it was abolished. Ashida accepted this offer on 7 June. ${ }^{29}$

Once it was decided to disband the Sensō Chōsa-kai, Shidehara drafted a revised 'plan for a civil research organization' and requested that the provisional committee members 'continue to cooperate. ${ }^{30}$ Shidehara's plan was for the work of the original committee to continue through the creation of an incorporated foundation. However, the GHQ would not allow it. At this point, Shidehara personally entrusted the matter to Aoki Tokuzō. 
Aoki proceeded to write a meticulous outline of the sequence of events leading up to the commencement of war with the US, taking the London Naval Conference on Disarmament as the starting point. Of course, Aoki made use of the historical documents that had thus far been collected by the Sensō Chōsa-kai. This was how Aoki came to write the sixvolume series Taiheiyō Sensō Zenshi (The prehistory of the Pacific War). This work omitted all subjective evaluation. It resembles a collection of historical material, just as Shidehara would presumably have intended for such an endeavour. In fact, Shidehara provided the foreword for this series, including the following line: 'I believe [this work] is sufficient for [the purposes of] convincing future generations of citizens, and for calling upon them to reflect'. ${ }^{31}$

It should be noted, however, that Shidehara's activity of determining the causes of the war was very much official in nature. Thus, these actions do not reveal what Shidehara thought as an individual about the issue of wartime responsibility. As it happens, Shidehara expressed his personal thinking on the subject after an unexpected event: the suicide of Konoe on 16 December 1945. Following Konoe's death, there were moves towards having his biography written. Shidehara was asked to formally initiate such an undertaking. However, he was unwilling to comply. His reasoning was that 'responsibility for causing the Pacific War lay above all with individuals like Duke Konoe and Lord Kido'. ${ }^{32}$

How would Shidehara have dealt with the military? Let us go back in time a few months to mention one more matter from this initial period of the Shidehara cabinet. At the end of November 1945, the cabinet decided to abolish the War Ministry and the Navy Ministry. To replace them in overseeing the ongoing demobilisation, on 1 December, the cabinet further established the Daiichi Fukuin-sho (First Demobilization Ministry) and the Daini Fukuin-sho (Second Demobilization Ministry). ${ }^{33}$ Shidehara himself took the responsibility of heading both of these ministries.

Shidehara observed that many of the survivors of the conflict 'had tasted the sorrow of disillusionment' upon returning to see their wartorn homeland. To this end, rather than merely discussing how to help the returnees with the Ministry of Health and Welfare or the Ministry of Justice, Shidehara made a plea on the radio for 'heartfelt solidarity between those returning and those who remained'. ${ }^{34}$ 


\section{The Shōwa Emperor}

\section{Amid Criticisms of the Emperor System}

When the Shidehara cabinet was formed at the beginning of October 1945, the GHQ ordered the Japanese government to release its political prisoners. This meant that the Japanese Communist Party was able to publicly resume its activities. Tokuda Kyūichi and other leaders of the Communist Party were particularly critical of the emperor system. The cabinet minister who reacted most strongly to the communists' criticisms of the emperor system was Narahashi Wataru, chief of the Cabinet Legislation Bureau. In a cabinet meeting, Narahashi proposed responding to the communists. Although Yoshida voiced his disagreement, Shidehara consented to the idea. Narahashi thereafter personally criticised the Communist Party on NHK Radio and argued for the continuation of the emperor system. ${ }^{35}$

Of course, it was not only the Japanese Communist Party that criticised the emperor system. In China and the US, much of the public regarded the Shōwa emperor himself as a war criminal. It was in this context that the US State-War-Navy Coordinating Committee reached out to MacArthur to seek his opinion on the matter. MacArthur responded that if the emperor were accused, it would lead to a chaotic situation for the occupation, and a million soldiers would be needed to maintain order. In other words, MacArthur responded to Washington by paradoxically stressing the usefulness of the emperor. ${ }^{36}$

Shidehara himself also worked to help preserve the emperor system. He began such efforts even before becoming prime minister. Shidehara anticipated that the emperor would eventually have the opportunity to speak with reporters from the New York Times on the matter. Therefore, towards the end of September 1945, he set about writing a draft in English for the emperor to utilise on such an occasion. In this draft, Shidehara noted that the imperial edict issued by the Tōjo cabinet announcing the war included the statement that specifics of wartime strategy 'should be left to the decision of the commander-in-chief of these forces'. ${ }^{37}$ In other words, Shidehara was careful that the emperor not mention Tōjō specifically. 
Taking this draft of answers into consideration, the emperor met with US reporters on 25 September. The press conference with the emperor proceeded much as Shidehara had anticipated. Nevertheless, the manner in which the New York Times reported on the emperor's response made it sound as though he was attempting to shift blame on to Tōjō. On this topic, a standard interpretation is that the summary of the meeting drafted by the newspaper was incorrect. ${ }^{38}$

However, the documentary records from the emperor's meeting with Frank Kluckhohn, reporter for the New York Times, state: 'His Majesty had no intention to have the war rescript used as General Tōjō used it'. ${ }^{39}$ If we take into account the contents of Kido's diary, we can infer another possibility: that the emperor himself told the reporter that it had been 'heartbreaking' to issue to Tōjō the imperial rescript for commencing the war. If that were the case, then it would mean that the emperor's statement went further than what Shidehara prepared for him. This is what the New York Times had suggested. Further, the article also appeared on the 29 September front page of the Asahi Shimbun. Upon seeing this, Shidehara could not help but be 'pained' at the 'audaciousness of the questioning' ${ }^{40}$

The first meeting between the emperor and MacArthur was held on 27 September. Almost all of what was said is known, as the historical records were recently made public. According to those meeting records, the emperor told MacArthur: 'With respect to the war, I myself wished to the fullest extent to avoid it. When I saw that the war would nevertheless take place, I felt the greatest regret'. ${ }^{41}$ Although the emperor did not mention Tōjō, his use of the expression 'regret' could be tied to theories of his responsibility for the war.

Exactly how Shidehara learned of the specifics of this first meeting is unclear. However, he was the type to go into the smallest details. Of the 11 meetings that eventually took place between the emperor and MacArthur, Shidehara received fairly accurate reports on at least some of them. Presumably, he received much of this information from contacts in the Ministry of Foreign Affairs. In the case of this first meeting, the emperor's statement that he felt 'regret' must have been cause for great concern for Shidehara, who viewed the wording as 'imprudent'. ${ }^{42}$ 
At around this time, the Treaties and Conventions Bureau at the Ministry of Foreign Affairs had begun to examine questions of the emperor's responsibility for the war from the perspective of the Meiji Constitution. According to the bureau, responsibility for beginning the war 'should be borne by the government, which was responsible for advising the emperor, and not by the emperor himself' ${ }^{43}$ On 5 November 1945, the Shidehara cabinet reached a decision on the problem of war responsibility. This cabinet decision stressed that the emperor was exempt from responsibility. More specifically, it stated that the emperor 'sought a peaceful settlement when it came to negotiations with the U.S.'. However, 'with respect to matters such as the decision to go to war and the carrying out of war strategy, he had no choice but to follow certain conventions established within the constitution'. ${ }^{44}$

On the surface, this may appear to be an example of the typical justification given by the Japanese side. In reality, the wishes of the GHQ were surely also at play here to some degree. After all, MacArthur had a positive attitude towards the emperor and fretted over the condemnation of him from the US public and the Soviets. Further, reports on MacArthur's disposition were relayed from Brigadier General Bonner F. Fellers, who was a close adviser to MacArthur, to Chief Cabinet Secretary Tsugita via former army lieutenant general Haraguchi Hatsutarō. ${ }^{45}$

\section{Declaration of Humanity}

On New Year's Day 1946, an imperial rescript was promulgated that denied the Shōwa emperor's divinity. This was known as the 'Declaration of Humanity'. However, aside from the imperial oath consisting of five articles at the beginning, the Declaration of Humanity was not conceived by the emperor himself. Here, too, Prime Minister Shidehara played a role. However, the primary leader of this undertaking is understood to have been Lieutenant Colonel H. G. Henderson, adviser to the GHQ Civil Information and Educational Section. There are also those who emphasise the guidance of Yamanashi Katsunoshin. Previously an admiral in the navy, Yamanashi had become president of Gakushūin. ${ }^{46}$

The Yamanashi Katsunoshin documents held at Gakushūin include an English-language draft of the Declaration of Humanity. In the margins of the draft, the following names are written: 'Dyke, Henderson, Blyth, Yamanashi'. The draft was written on 15-20 December 1945. Here, the names 'Dyke' and 'Blyth' refer to Ken R. Dyke, chief of the 
Civil Information and Educational Section, and R. H. Blyth, a teacher at Gakushūin. Notes written on the Yamanashi document also state the following:
A (written by Blyth) $\rightarrow$ minister of the imperial household $\rightarrow$ emperor $\rightarrow$ minister of the imperial household $\rightarrow$ vice-minister, Asano $\rightarrow$ (Foreign Minister Yoshida $\rightarrow$ prime minister $\rightarrow$ Foreign Minister Yoshida) $\rightarrow$ vice-minister $\rightarrow$ Asano $\rightarrow$ Mr. B $\rightarrow$ Henderson + Dyke $\rightarrow$ M'Arth.
Approval of M'Arth $\rightarrow$ Mr. B $\rightarrow$ Asano $\rightarrow$ minister of the imperial household, vice-minister $\rightarrow$ emperor $\rightarrow$ prime minister $\rightarrow$ Cabinet council etc. $\rightarrow$ Proclamation. ${ }^{47}$

To clarify, what it states is that the English-language draft was given to the Japanese side by Blyth. It then passed through the hands of individuals such as Minister of the Imperial Household Ishiwata Sōtarō, ViceMinister of the Imperial Household Ōgane Masujirō and Gakushūin administrative official Asano Nagamitsu, before eventually reaching Prime Minister Shidehara. The Yamanashi document notes also feature the statement: 'This draft has been shown beforehand to Dyke-M'ck, in order to receive their input'. ${ }^{48}$ Of course, the names 'M'Arth' and ' $M$ 'ck' in these notes refer to MacArthur. In summary, although the proposal for the Declaration of Humanity originated on the GHQ side, its actual contents were a joint effort between the Japanese and US sides. Naturally, this joint effort included Shidehara.

On 25 December, as hunger and bitter cold swept over the ruins of Tokyo, Shidehara continued to work on the English-language draft of the Declaration of Humanity at the Prime Minister's Office. For this task he had the consent of the GHQ, as well as the approval of the emperor, received via Maeda, the minister for education. As it happens, Kinoshita Michio, the deputy grand chamberlain, was critical of Shidehara's draft. Specifically, he was resistant to a document such as this that denied the emperor's divinity. Yet, Shidehara fought this opposition. 'To change the meaning of the text now that it has been shown to MacArthur', Shidehara stated, 'would trespass against the faith [he has put in us]'.49 Shidehara collapsed the following morning with acute pneumonia, due to his exhausting workload. He was eventually confined to bed to recover. Upon learning about Shidehara's illness, MacArthur personally ensured that he received a special delivery of penicillin. 
Thus, on New Year's Day 1946, the morning editions of the nation's newspapers published the imperial rescript, which began: 'We are together with thee, the citizens'. It would later become known as the Declaration of Humanity. These morning editions also displayed unprecedented pictures of the emperor wearing a regular suit. The public had never seen him shown in such a manner before. At this time, Shidehara issued his own comment as prime minister: 'Carrying out the will of our lord's imperial command, we will build a new nation that is permeated with the ideals of democracy, pacifism, and rationalism'. ${ }^{50}$ Of course, what Shidehara meant by 'democracy' was something different from the Western-style concept. For Shidehara, Japanese democracy was to be developed on the basis the emperor's five-article imperial oath.

Some at the time were aware of Shidehara's involvement in the emperor's Declaration of Humanity. ${ }^{51}$ The Shōwa emperor himself acknowledged this in the late 1970s, when he made the following public statement:

The first goal of that declaration was the imperial oath. The matter of divinity [its rejection] was actually a secondary matter ... I think it was very necessary at that time to point out that democracy was not an import from outside ... I also spoke with Prime Minister Shidehara Kijūrō. When the prime minister showed [the draft] to Supreme Commander MacArthur of the GHQ, he responded very positively, praising it for 'being excellent beyond expectations,' and was strongly in favor of the whole text being published. Hence it was decided to release the entire text. ${ }^{52}$

Although the emperor claimed that the rejection of his divinity was 'a secondary matter', this interpretation differs from Shidehara's intention. I note that Shidehara had also suggested to the emperor that he consider conducting an imperial tour of the nation and bestow funds from the imperial household finances to the people..$^{53}$

There are other details that help to paint a picture of Shidehara's perception of the imperial household. At that time Japan was suffering from food shortages. Shidehara told Finance Minister Shibusawa: 'Japan has run out of food. If we do not ask the U.S. for food aid, then Japanese people will starve to death'. Casting about for ideas, Shibusawa even urged Shidehara: 'Please send the crown prince to study in the U.S.'. Shibusawa worried that the US might not send enough food unless Japan signalled its obedience by sending its crown prince there as a hostage, so to speak. This gives us some idea of just how concerned he was about the situation. 
Shidehara declined Shibusawa's request on the spot: 'I cannot present such a discourteous request to His Majesty'. ${ }^{54}$ At a loss as to what should be done, Shibusawa could only weep.

\section{Establishing the New Constitution}

\section{The Constitutional Problems Investigation Committee}

Another ordeal awaited the Shidehara cabinet after the Declaration of Humanity. This was the mass purging of individuals from public office on 4 January 1946. Five ministers from the Shidehara cabinet were among those purged that day. Furious, Shidehara summoned Chief Cabinet Secretary Tsugita to his sickbed and began to fiercely criticise MacArthur:

That bastard Mac, to give such a ridiculous order ... I simply cannot agree to this. I cannot execute such orders. I am unable to force out my cabinet ministers who have worked with me up until today, so I am determined instead to trigger a mass resignation of the cabinet. Please tell the ministers of my decision and gather all their letters of resignation..$^{55}$

In sum, Shidehara informed Tsugita that he had decided that the cabinet should resign en masse. However, he tearfully retracted this decision after strenuous persuasion by Matsumura, the minister for agriculture.

Hence the Shidehara cabinet was instead reshuffled. Along with Chief Cabinet Secretary Tsugita and Agriculture Minister Matsumura, the five ministers forced to resign included Home Minister Horikiri, Education Minister Maeda and Transport Minister Tanaka. Their respective positions were filled by Narahashi Wataru, Soejima Senpachi, Micchi Chūzō, Abe Yoshishige and Murakami Yoshikazu. As Narahashi took on the role of chief cabinet secretary, the now-vacated chief of the Cabinet Legislation Bureau was in turn filled by Ishiguro Takeshige. The GHQ Government Section was critical of this reshuffle. ${ }^{56}$

The most serious point of contention during the cabinet reshuffle was that of constitutional reform. In truth, Shidehara was not enthusiastic about the proposition. When Shidehara originally formed his cabinet at the beginning of October 1945, he had expressed the opinion that constitutional reform ought to be carried out 'extremely passively, with 
changes made [only] as specific needs arose ${ }^{57}$ Nevertheless, he also felt that if the US demanded constitutional reform, it would be difficult to resist. On 13 October of that same year, the cabinet decided to establish the Constitutional Problems Investigation Committee. The committee chairman was State Minister Matsumoto Jojji. The committee members included scholars such as Miyazawa Toshiyoshi, Chief of the Cabinet Legislation Bureau Narahashi, Cabinet Legislation Bureau First Department Director Irie Toshio and Second Department Director Satō Tatsuo. ${ }^{58}$

That said, Shidehara's intention was to examine whether constitutional reform was even required. His establishment of this committee did not mean he had committed to a course of reform. Although the Constitutional Problems Investigation Committee convened at the meeting room of the prime minister's official residence, there is practically no evidence that Shidehara actually offered the committee any guidance. Indeed, the committee itself was entirely unofficial. Moreover, Shidehara was at a loss when it came to dealing with Konoe Fumimaro, who pushed for constitutional reform from outside of the cabinet. ${ }^{59}$

Another occasion when Shidehara revealed his perspective on constitutional matters was his address to the House of Representatives on 28 November 1945. To a question from Saitō Takao, Shidehara responded that it was still premature to speak of reforming the constitution. As he stated: 'The articles of the imperial constitution are highly flexible and do not obstruct the development of democracy'. At the same time, Shidehara noted that while the Meiji Constitution could operate in a flexible manner, it might also need some revisions to 'put an end to long-running concerns over its abuse'. ${ }^{60}$ Shidehara's thinking on the matter was two-tiered, as it were. Therefore, while the kind of constitutional reform Shidehara had in mind was not comprehensive, he did not think to stand by idly. From the outside, he may have appeared to be merely indecisive. George Sansom, an old acquaintance who was visiting Japan at this time, wrote that Shidehara:

Is old and tired ... [He] had no experience in domestic politics ... [and] was interested more in the past than the future ... [He was] a melancholy figure certainly unfit to lead his country in a desperate crisis. ${ }^{61}$

Sansom was then serving as the British representative to the Far Eastern Advisory Commission. 


\section{The Origin of Article 9}

One of the problems that arises when considering the history of this period is the origin of Article 9 of the Japanese constitution. This is the famous article that prevents Japan from participating in wars. Although some have theorised that MacArthur proposed Article 9, MacArthur himself stated that the article was based upon a proposal from Prime Minister Shidehara. It has been said that MacArthur and Shidehara had a debate over this article during a meeting between the two on 24 January 1946. Shidehara had returned to his duties following his recovery only three days earlier. According to his close friend Ōdaira Komatsuchi, Shidehara had initially visited MacArthur to thank him for the penicillin he had received. However, recalls Ōdaira, Shidehara also used the opportunity to 'tell MacArthur that he wanted to maintain the emperor system, no matter what, and wanted to know if he would receive MacArthur's cooperation in that respect'. MacArthur responded by 'promising that he wanted to cooperate as much as possible, which was a great relief for Shidehara' ${ }^{62}$

Shidehara also reportedly:

Began to talk about how, for some time, he had thought that in order for the world to give up on military force, in order for that ideal to be realized, and for the world as a whole to stop engaging in war, the only way would be [for nations] to renounce the right to wage war. As it happened, MacArthur suddenly stood up and grasped Shidehara's hand with both of his hands and expressed his heartfelt agreement with tears in his eyes, such that Shidehara was quite surprised for a moment. ${ }^{63}$

For the most part, both Shidehara and MacArthur placed the highest importance upon the continuation of the emperor system. 'Clearly announcing to the world' that Japan renounced the waging of war has hence been understood by commentators as a method for achieving this end. In other words, it was necessary to renounce war in order to placate international opinion, which had thus far been critical of the emperor system. It must be added that, at this point, the Japanese side had just begun to prepare a draft of the revised constitution. They had no way of foreseeing that the GHQ would produce its own draft. Further, Shidehara's talk of renouncing war had, at that stage, been only an expression of ideals. It is hard to imagine Shidehara proposing that such an article be included in the constitution. Yet, this is just what MacArthur would soon work towards having incorporated into the draft. 
At any rate, it is important to clarify the context within which Shidehara mentioned the renunciation of war. Fortunately, some details on this matter appear in the unearthed correspondence of Shiratori Toshio. The former diplomat Shiratori had been arrested and detained in Sugamo Prison as a suspected A-class war criminal. On 10 December 1945, Shiratori composed a letter in English to Foreign Minister Yoshida, stating that it was necessary to carry out 'a totally new departure in constitutional legislation ... binding up that [peace] clause indissolubly with the provisions concerning the Emperor' ${ }^{6}{ }^{64}$ In other words, Shiratori proposed including a renunciation of war in the constitution in order to protect the emperor system. Shiratori asked Yoshida to make a copy of his letter and provide it to Shidehara. However, the letter was held by GHQ censors until 20 January 1946.

Later, at the Tokyo Trial, former diplomat Hirota Yōji acted as Shiratori's assistant counsel. According to the affidavit of Yoshida Shigeru, as prepared by Hirota, Shiratori had met with Yoshida just before his detention. On that occasion, he told Yoshida that he wished to speak with Shidehara on matters that included a proposal for a new constitution. Upon hearing this, Yoshida requested that he put the details of this request in writing, which Shiratori then did. This is why Yoshida would later hand a copy of Shiratori's letter to Shidehara. Shidehara is believed to have received Shiratori's letter directly after its release by the GHQ censors, around 20 January 1946. If that was the case, it means that Shidehara would have had the chance to look at Shiratori's letter just before the 24 January meeting with MacArthur. Therefore, Shidehara's mentioning of the renunciation of war during that meeting may well have occurred as a result of his coming into contact with that letter. ${ }^{65}$

Did Shidehara's talk of renunciation of war bring about the inclusion of Article 9 in the new constitution? Drawing upon comments by Shidehara's secretary, Kishi Kuramatsu, Hirota Yōji says the following about the 24 January meeting between Shidehara and MacArthur:

It is true that Prime Minister Shidehara had spoken of the idea, or the ideal of renouncing war, and that General MacArthur completely agreed with him on the matter. However, they did not at all discuss the inclusion of any such provision in the Japanese constitution. That is why, when the U.S. draft of the Japanese constitution was shown to the Japanese side on February 19 [sic.], even the prime minister appeared somewhat surprised. Even the Matsumoto draft that the Japanese side created contained nothing 
remotely like the renunciation of the right to wage war. This is because Mr. Shidehara never thought to use the constitution to prescribe such a thing. ${ }^{66}$

In other words, while Shidehara and MacArthur had seen eye to eye on the topic of renouncing war, this was simply at the level of an ideal, and not as an article in the constitution. Further, when Hirota visited Shidehara and Yoshida:

The two of them said that they had read Shiratori's letter. However, they would not tell me anything at all about how they would respond to his war renunciation proposal, or the other contents of the letter. ${ }^{67}$

We can surmise that what Shiratori had in mind when he composed his letter was something like the Kellogg-Briand Pact of some 20 years prior. This pact was named for the US secretary of state and the French foreign minister who spearheaded its formulation. The Kellogg-Briand Pact included the renunciation of warfare as an instrument of national policy, prescribing that arguments between nations were to be resolved peacefully. It was signed in Paris in August 1928. When plenipotentiary representative Uchida Yasuya signed the pact in Paris, Shiratori had been present as his attendant. For this reason, Shiratori was well acquainted with the details of the pact.

Thus, it is possible that the spirit of the Kellogg-Briand Pact had a real impact on MacArthur, via the mediation of Shidehara's comments following his reading of Shiratori's letter. However, it should be noted that, through its censors, the GHQ would have known of Shiratori's war renunciation proposal before Shidehara did. Further, although Shidehara spoke of the renunciation of war after seeing Shiratori's letter, his comments were, as noted above, only at the level of ideals. He did not propose incorporating a war renunciation article into the constitution. It is also worth pointing out that Shiratori hoped to use this letter at the Tokyo Trial as proof of his own pacifism. ${ }^{68}$

At a cabinet meeting held on 30 January 1946, Matsumoto reported on the progress of the Constitutional Problems Investigation Committee. The cabinet subsequently deliberated upon topics such as Matsumoto's own proposal for constitutional reform. In this proposal, Shidehara stated that the article on the emperor left the relationship between 'His Majesty' and 'inviolable' unclear. Shidehara further argued emphatically that the military provisions needed to be removed from the constitution draft: 
If we leave military provisions in the constitution, then the Allies will definitely come and complain about it. I am concerned that it may be a problem if, at the present time, we place a provision in the constitution with the premise that we would be able to have a military in the future. Won't we end up spending one, two months in negotiations with headquarters [GHQ] for the sake of this provision? ... Thinking [of the matter] from the perspective of the general world situation, our nation may well be able to have an army again one day. However, I think it would be too provocative to put this provision in here today. ${ }^{69}$

What Shidehara had in mind with this statement was the planned submission to the GHQ of the Japanese constitutional draft. The Japanese proposal did not strongly reflect Shidehara's own intentions. On top of that, it was rejected by the GHQ. This makes it unlikely that Shidehara was the one who originally proposed Article 9.

A record of an interview conducted at this time has been preserved in a collection of Shidehara's personal documents. According to these records, Shidehara asserted that 'a liberal democratic system with the Emperor as constitutional monarch is the only regime that will prove stable and beneficial for Japan'. He added:

The constitution of Japan should not be an exact reproduction of the British or any other monarchical system ... it must be adapted to the Japanese character and traditions. ${ }^{70}$

Here, too, Shidehara was thinking mainly of the emperor system.

\section{The Emperor System and Renouncing the Right to Wage War}

A significant turning point came on 1 February 1946. Nishiyama Takichi, a journalist for the Mainichi Shimbun, published a scoop on the conservative draft plan of the Constitutional Problems Investigation Committee. The Mainichi Shimbun editorial launched the following criticism:

When it comes to what may be regarded as the core of the constitution, the sovereignty of the emperor, this new plan is based on exactly the same principles as the current constitution. ${ }^{71}$ 
Surprised by the conservative plan for constitutional reform that the Japanese side had devised, the GHQ began work on its own proposal for a new constitution. However, if Nishiyama had not succeeded in securing the above scoop, the GHQ's draft might well have arrived much later, and, as a result, led to further chaos.

The above circumstances show that the only way that Shidehara could have been responsible for introducing Article 9 into the new constitution is if the prime minister had buried the conservative Japanese draft and instead endorsed the GHQ draft. Information could potentially have been purposely leaked to the press to such ends. Indeed, from the outside, the Mainichi Shimbun scoop does look as though it might have been the result of such a political manoeuvre. However, Shidehara was not the source of Nishiyama's information. We know this because Nishiyama himself has spoken out on the matter, stating that Shidehara 'absolutely did not allow reporters to approach him' and that, in any case, Shidehara 'hated newspaper reporters. ${ }^{72}$ It is therefore difficult to imagine that Shidehara would leak the Japanese draft. Nishiyama has also said of Shidehara:

The symbolic emperor system uniting the citizens and the emperor constitutes the underlying framework of postwar Japan, and it was Shidehara (Kijūrō) who created it. He was a great figure. Mr. Yoshida (Shigeru) is lionized these days; however, I want the young people of today to know about Mr. Shidehara. ${ }^{73}$

On 3 February, MacArthur's three basic principles on constitutional reform were shown to Courtney Whitney, chief of the GHQ Government Section. These three basic principles were the emperor system, the renunciation of war, and the abolition of feudalistic systems. Here, the retention of the emperor system was combined with the renunciation of war. In other words, MacArthur was concerned about the Far Eastern Commission, which was critical of the emperor system. ${ }^{74}$ The Far Eastern Commission was a policymaking body focused on Japan that the Allied nations had set up in Washington. Its establishment had been decided upon at a foreign ministers' conference in Moscow in December 1945.

On 8 February 1946, the Japanese side submitted a general outline of its proposal for constitutional reform to the GHQ. This outline was not reflective of the views that Shidehara had earlier expressed at the cabinet meeting on 30 January. ${ }^{75}$ Moreover, not only did the GHQ have a poor impression of the reform outline, but also they viewed it as effectively preserving the Meiji Constitution. 
As a result, the initiative for reforming the constitution shifted entirely to the GHQ. As early as 13 February, Whitney and Colonel Charles L. Kades handed over a copy of their own draft, known as the 'MacArthur Draft', to Matsumoto and Yoshida. Matsumoto and Yoshida had only expected to hear GHQ's opinion of the revisions proposed by the Japanese side. When they were suddenly shown this 'MacArthur Draft', they were shocked, especially once they saw its contents. With Shidehara's assistance, Matsumoto submitted a supplementary explanation on the Japanese proposal to GHQ. However, Whitney not only replied that there was no leeway for reconsideration but also warned him that if they did not receive a response by 20 February, they would publicly announce the GHQ proposal. ${ }^{76}$

Left with little choice, Shidehara slipped out of the Prime Minister's Office on 21 February and paid a visit to MacArthur. Their discussion lasted a full three hours. MacArthur argued that, although he very much wished to keep the emperor's position secure, the Far Eastern Commission was taking a hard line. It was therefore necessary for GHQ to create a proposal that would prescribe both the symbolic emperor system and the renunciation of war. MacArthur further stated that he thought 'Japan should take moral leadership [on this matter] by declaring it will renounce its right to wage war'. In response, Shidehara replied: 'It might be called leadership, but I doubt that there will be any followers'. MacArthur immediately countered: 'Even if there are no followers, Japan has nothing to lose'. ${ }^{77}$ On the following day, 22 February, after a visit to the Imperial Palace, Shidehara reported to the cabinet on his meeting with MacArthur. Matsumoto responded in a raised voice:

As can be clearly seen from precedents such as Germany and South America, constitutions that are pressed upon a nation from the outside are, in the end, not deserving of observance. ${ }^{78}$

Yet Shidehara believed there was 'some room for compromise' regarding the GHQ proposal. ${ }^{79}$ What finally convinced Shidehara was MacArthur's argument that if Japan did not accept the US proposal, he would be unable to guarantee the survival of the emperor system. To put it another way, the emperor system could be protected by codifying Japan's renunciation of war. This may well have been why Shidehara returned from his meeting with MacArthur 'in a slightly cheerful mood' ${ }^{80}$ 
Shidehara took the further step of revising Article 1 of the Japanese proposal. It now stated that the emperor was a symbol that was based upon 'the supreme collective will of the Japanese people'. ${ }^{81}$ Shidehara also changed the prescriptions on constitutional reform, allowing them to take place via special national referendums, and not merely at the time of general elections. Following further consultation with GHQ, on $6 \mathrm{March}$, the cabinet was able to announce a summary of its constitutional reform proposal. When giving his statement, Shidehara emphasised Japan's renunciation of the right to wage war.

There was a suitable reason for expediting the process. On 27 February, the Yomiuri Höchi had reported that 'the emperor wished to abdicate'. ${ }^{82}$ The source of this report was Prince Higashikuni. So, the cabinet finally agreed to accept the GHQ proposal on 5 March, following a visit to the Imperial Palace by Shidehara and Matsumoto to gain the emperor's approval. This was the moment in which the basic political framework for postwar Japan was decided. The cabinet meeting held that day stretched late into the night, and more than a few of the cabinet ministers had tears in their eyes. Before his assembled ministers, including Yoshida and Matsumoto, Shidehara concluded the cabinet meeting with the following words:

It is an extremely serious responsibility to accept such a constitutional draft. In all likelihood, it is a responsibility that will have an impact upon our descendants. If we announce this plan, there shall be some who will praise it. There shall also be those who will remain silent, yet their hearts will surely be filled with a deep indignation at our attitude. However, when we take a broad view of the situation, we can see that today there is no other path that we can take. ${ }^{83}$

Shortly afterwards, on 20 March, Shidehara attended a plenary session of the Privy Council. There Shidehara sought to convince those present that the renunciation of war was important to protect the emperor system. Shidehara told them frankly that, due to the involvement of the Far Eastern Commission, MacArthur had been able to 'suddenly rush the announcement of the constitution draft in order to create a situation where everything had already been effectively decided'. ${ }^{84}$

On 22 April, Shidehara gave an even more detailed explanation to the First Privy Council Investigative Committee for Proposed Revisions to the Imperial Constitution. Shidehara also frequently spoke with Suzuki Kantarō, who was then serving as the chairman of the Privy Council. ${ }^{85}$ 
Meanwhile, although the Constitutional Problems Investigation Committee would never again convene, it was not actually abolished. This was due to Shidehara's concern for Committee Chairman Matsumoto. What gave Shidehara the most reason for anxiety was the 'rumour' that Article 9 had been forced upon Japan by the US. He responded by making sure that all officials had their story straight: it was a proposal from the Japanese side. ${ }^{86}$

Shidehara's reshuffled cabinet paved the way for constitutional reform. When Shidehara said to Kanamori Tokujirō that 'we absolutely must push for a peace constitution that renounces war', his intention was to protect the emperor system. He understood that it was possible for a clause renouncing war to one day be changed. Yet if the emperor system were abolished, the loss would be irreversible. In a meeting with the emperor, MacArthur also made the following meaningful statement: 'Thanks to His Majesty's assistance, the constitution is now ready. [Smiling] If we did not have His Majesty, we would not have this constitution'. ${ }^{87}$

\section{Resignations of the Shidehara Cabinet}

\section{Inauguration as President of the Progressive Party}

Along with the problem of the constitution, Shidehara's reshuffled cabinet was also tasked with the challenge of improving the lives of the citizenry. The opposition party had been severely denouncing Shidehara over the tightening of supply restrictions and the rationing system. In a letter to Izawa, he expressed the feeling of being 'surrounded by enemies on all sides'. ${ }^{88}$

From the outset, the Shidehara cabinet had been regarded as a 'stopgap cabinet'. Its most important mission was to carry out electoral reform and an election for the House of Representatives. That is to say, the calling of a general election was seen as the cabinet's primary purpose. It was expected, as it were, 'to serve as a midwife for the establishment of democratic politics' ${ }^{89}$ Once the Shidehara cabinet had revised the electoral law in December 1945, the next general election was scheduled for April 1946. It was the first postwar election, as well as the first election in Japan where women received suffrage. In a radio broadcast, Shidehara appealed to the significance of 'this election as the departure point for democratic politics in our nation'..$^{90}$ Yet he made no comment as to what course of action ought to be pursued following the election. 
When the election was held on 10 April 1946, the leading party was Hatoyama Ichirō’s Liberal Party (Jiyūtō). The runner-up was the Japan Progressive Party (Nihon Shinpotō), followed by the Japan Socialist Party (Nihon Shakaitō). However, the Shidehara cabinet would not readily step down. This was because, even though the Liberal Party took first place, it had secured less than a third of the seats in the house. The work of establishing the new constitution was also yet to be completed. Mitsuchi, Narahashi and Ishiguro were particularly eager to see the cabinet continue. For this reason, Shidehara-who had once served as foreign minister in the so-called Goken Sanpa coalition cabinet-was now the target of public criticism for his 'turncoat scheming'. In the end, the Shidehara cabinet resigned on 22 April. On 23 April, Shidehara agreed to serve as president of the Progressive Party. For the first time, Shidehara joined a political party, probably because he wished to ensure that constitutional reform was carried out correctly. ${ }^{91}$

The Progressive Party that Shidehara now presided over had been formed in November 1945. Despite its name, it was actually a conservative political party, and the only party in power that had previously lent its support to the Shidehara cabinet. Initially, the party found it difficult to select a president. Eventually the role was filled by Machida Chūji, but he was soon caught up in the aforementioned purge of public officials. The Progressive Party suffered a major defeat in the general election of April 1946, ceding the position of leading conservative party to the Liberal Party. As for its alignment, the party understood itself to be 'to the right of the Socialist Party and to the left of the Liberal Party'. ${ }^{92}$

Following the resignation of his cabinet, Shidehara intended to formally petition the emperor to have the Liberal Party president Hatoyama Ichirō become the next prime minster. On 4 May he sought informal consent for this move from MacArthur, via Yoshida’s mediation. Just after sending this request, however, even Hatoyama fell victim to the purge of officials. He would be replaced by Yoshida. Shidehara thereafter sought to have Yoshida installed as prime minister. On 15 May, he had Yoshida himself make this request to MacArthur, who granted his approval. ${ }^{93}$

\section{From the Democratic Party to the Liberal Party}

On 16 May 1946, Shidehara formally recommended Yoshida Shigeru to the imperial throne as the next prime minister of Japan. The Yoshida cabinet was formed on 22 May as a coalition cabinet containing ministers 
from both the Liberal Party and the Progressive Party. As president of the Progressive Party, Shidehara entered the cabinet as minister of state. ${ }^{94}$ As a minister without a portfolio of his own, Shidehara was assigned to deal with constitutional reform and also sought to work on policy relating to the Diet.

On the Progressive Party side, the cabinet included figures such as Saitō Takao, who served as an adviser, and Inukai Takeru, who was the chairperson of the general affairs committee. ${ }^{95}$ However, alongside such allies, Shidehara also had to endure working with Ashida Hitoshi from the Liberal Party. Although Ashida had previously served as health and welfare minister in the Shidehara cabinet, they did not see eye to eye. When Shidehara sought to have the two parties coordinate their efforts, Ashida instead argued for a three-party coalition that included the Socialist Party. This disagreement had deepened the divide between the two.

In correspondence sent to Shidehara when he was prime minister, Ashida wrote:

Regrettably, it seems that one or two ministers have sought to create a ruling party that supports the cabinet by shifting their political alignments. I believe that at this present crucial moment, such actions may push the political world in a more chaotic direction and give rise to anxiety among the citizenry. ${ }^{96}$

Discontented with these developments, on 19 April 1946, Ashida submitted to Prime Minister Shidehara his resignation as minister of health and welfare 'due to personal circumstances'. ${ }^{97}$ Just after this, however, the Shidehara cabinet resigned en masse.

Before long, the Yoshida cabinet also began to run into difficulties. It was at this time that Ashida decided to visit Shidehara. The day was New Year's Eve 1946. Ashida asked Shidehara if he would consider becoming prime minister once more, this time of a three-party coalition cabinet that would include the Socialist Party. Yet Shidehara replied that he instead 'wanted to find a way of pushing ahead with some reshuffling. ${ }^{98}$ Meanwhile, there were disquieting movements in the Progressive Party. Hori Shigeru of the Progressive Party approached Ashida and informed him that 'there are those [in the party] who would be comfortable with pushing Mr. Shidehara out'. ${ }^{99}$ Progressive Party reformists became bolder and began rallying around younger figures such as Inukai Takeru. This inner discord would lead to the dissolution of the party on 31 March 1947, 
and the subsequent founding of a new party known as the Democratic Party (Minshutō). The Democratic Party also gathered members from the National Cooperative Party (Kokumin Kyōdōtō). At this time, Shidehara was focused on the coming general election and wanted Yoshida's Liberal Party to merge with the remnants of the Progressive Party. However, the Liberal Party was not amenable to this idea. Left with no other choice, Shidehara participated in the creation of the Democratic Party, out of the core of the old Progressive Party.

Although Shidehara was successful in the April 1947 election, he had lost the favour of the general public. The Democratic Party did not get around to selecting its very first leader until after the election. The position would go to Ashida, who had previously left the Liberal Party. Having lost out to Ashida, Shidehara was instead elected honorary president of the party. Although the Democratic Party had the most House seats at the time of its formation, in the fourth general election it slipped to third place. In fact, it was the Socialist Party that took first place in the election, with Yoshida's Liberal Party pushed into opposition in second place.

Katayama Tetsu, chairman of the Socialist Party, formed a new cabinet towards the end of May. Democratic Party President Ashida formed a coalition with the Katayama cabinet, taking the role of foreign minister for himself. In other words, the Katayama cabinet was a coalition cabinet consisting of ministers from the leading Socialist Party, as well as from the Democratic Party, which had come in third. Shidehara was particularly displeased with the Democratic Party for this decision. He had wished to merge the party with the Liberal Party but was ultimately unable to. Although he did not go so far as to leave the party, at the end of May he submitted his resignation as honorary president, arguing for the 'levelheaded development of the party'. ${ }^{100}$ In the Democratic Party were some 30 individuals who were viewed as belonging to the Shidehara clique, including Hitomatsu Sadayoshi, minister of health and welfare.

Significantly, it appears that GHQ's Government Section played some role in Ashida's rise to the position of Democratic Party president. While Shidehara promoted a 'conservative coalition' between the Democratic Party and the Liberal Party, there is a theory that the Government Section was against this idea. It seems likely that Shidehara was not sufficiently aware of this fact. At any rate, Shidehara was not at all comfortable with Ashida's rise to party president. As for these movements, there were also dark rumours in the air relating to money. A supremely proud 
individual, Shidehara felt humiliated. His ill feelings towards Ashida never disappeared. ${ }^{101}$ Ashida, meanwhile, focused on creating a gathering of political moderates.

At the end of November 1947, Shidehara left the Democratic Party altogether. The direct cause was his voting against the Katayama cabinet's proposed Coal Mining Nation Management Law. Twenty-two members of the Shidehara clique left the Democratic Party with him, and together they created a new party called the Dōshi Club. This meant that Shidehara was once again in political opposition.

Shidehara disclosed his intentions in a letter he wrote on New Year's Day 1948, addressed to Ishibashi Tanzan, who was still barred from public office:

\section{Happy New Year}

It has been some time since I had the pleasure of seeing you. When I reminisce about those happier days when I had the honor of speaking with you regularly, I am filled with a vague sense of loneliness.

As you are aware, I find myself deploring the current state of events in the political world and have resolutely decided to end my ties with the Democratic Party. It has become necessary for me to push forward on the basis of my own convictions.

From the beginning, I have tried not to dwell upon such matters as the collapse of the current cabinet or the future of the administration. Rather, I have only hoped that affairs of state might be carried out smoothly, and that we might keep the political situation stable.

I am aware that it would be absurd for this failure of an old man to continue in such farcical performances. And so, I have set sail on this voyage. Until I arrive at my port of destination, I beg you to take into consideration the real state of affairs.

These days it grows ever colder, and I pray that you will take all the more care of your health.

Respectfully yours,

New Year's Day

Kijūrō

Ishibashi Kendai Jisō ${ }^{102}$ 
Upon receiving this letter, Ishibashi noted that he 'felt a special affection for Mr. Shidehara'. ${ }^{103}$

Before long, the Katayama cabinet entered a deadlock with the Socialist Party over a budget proposal. On 10 March 1948, it was replaced by the Ashida cabinet. The Ashida cabinet was a coalition, containing ministers from the Socialist Party, the Democratic Party and the National Cooperative Party.

Following this event, Shidehara formed a political party known as the Democracy Club with 36 other individuals, including Saitō Takao, who had also left the Democratic Party at that time. Only a few days later, on 15 March, it merged with Yoshida's Liberal Party. This was the birth of the Democratic Liberal Party (Minshu Jiyūtō). Apart from Yoshida, who served as president, leaders of the Democratic Liberal Party included such figures as Shidehara, who was appointed 'supreme adviser', and Yamazaki Takeshi, who was secretary-general. At its founding, the Democratic Liberal Party was the strongest party in Japan, boasting 152 members in the House of Representatives. Among those politicians who had followed Shidehara out of the Democratic Party and into the Democratic Liberal Party, there was a young lawmaker by the name of Tanaka Kakuei; he would become prime minister one day. When the second Yoshida cabinet was inaugurated in October that year, Tanaka would become the parliamentary vice-minister of justice on the basis of a recommendation from Shidehara. ${ }^{104}$

\section{'Those I Will Never Forget'}

I would like to conclude this chapter by probing the relationship between elections and political parties in Japan at this time. Shidehara had faced the election of April 1946 as prime minister. Yet he remained a member of the House of Peers without having to run as a candidate. The House of Peers would later be abolished on 3 May 1947, as a result of the new constitution coming into effect. By then over 20 years had passed since Shidehara became a member in 1926. Following the enactment of constitutional reform, fresh elections were held for the House of Representatives and the new House of Councillors (the upper house) in April of the same year. Shidehara would run as a candidate for the House of Representatives and subsequently won election to the Diet for the first time.

Shidehara was voted into office a total of two times in his life: the first in the aforementioned election of April 1947, and the second in an election held in January 1949. While Shidehara ran as a representative 
for the Third Ward of Osaka prefecture, he continued to live in Tokyo; his formal residence was in Sendagaya, and his actual residence was in Setagaya. Already over 70 years old when he first joined a political party and became president of the Progressive Party, Shidehara would have understood that he was not the type of politician who could count on popular support. He nevertheless sought to lead a political party late in life because he believed it necessary to stabilise Japan's political situation with a conservative coalition. From Shidehara's perspective, a bulwark was needed to shield the nation from the chaos that could arise in the wake of such challenges as the ongoing purging of public officials. However, as shown above, it was due to this same 'conservative coalition theory' that Shidehara lost his chance to lead the Democratic Party. Shidehara was not adept at the kind of manoeuvring necessary for a party politician.

Yet, after entering the world of party politics, Shidehara devoted a great deal of attention to both domestic affairs and diplomatic matters. There had long been an unwritten law among Foreign Ministry officials that they did not become involved in domestic affairs. This attitude was practically an article of faith for Shidehara in the prewar era. He also saw it as the price that needed to be paid for the centralisation of diplomacy under bureaucratic control. Hence, although implored by Hamaguchi, Shidehara had been entirely unwilling to accept the position of party vice-president. In his memoirs, he wrote:

I took the ideological position that the foreign minister must not be connected to a political party. At that time, I had no interest at all in getting involved in politics. ${ }^{105}$

However, under the conditions of postwar democracy, the Ministry of Foreign Affairs was no longer in a position to fully control diplomatic efforts. In due course, political parties would begin to involve themselves in diplomacy. Thus, it became necessary to rethink the connection between domestic affairs and diplomacy. Shidehara's position therefore gradually underwent a metamorphosis. Towards the very end of his life, upon becoming speaker of the House of Representatives, Shidehara soon became engaged in nonpartisan diplomacy. I will discuss this topic in the following chapter.

There is also the question of Shidehara's reaction to the postwar era. In fact, by no means did he have a higher regard for it. In a 1951 essay, he wrote: 
These days I do not even have any interests ... My greatest pleasure would simply be to have an interesting book to read. But even if I go and visit Maruzen [a major Japanese bookstore], I am unable to freely order foreign books like I used to. Things have become altogether inconvenient.

\section{Shidehara went on to say:}

I think politicians of the prewar era were also most serious ... Nowadays it has become common to say that people of the previous generation were entirely feudalistic in their thinking and so on. I have the impression that people who say such things are actually merely shallow. For example, whether it is freedom of thought, or whether it is democracy, I think there are more than a few people who do not look at such matters from the perspective of obligations or responsibilities; they simply believe that freedom and democracy mean being free to do as they please. This tendency is really worrisome, in my opinion. However, it may be that I am simply incapable of holding forth on postwar matters.

Shidehara reserved his highest praise for prewar politicians such as Itō Hirobumi and Saionji Kinmochi. In the case of foreigners, those he 'could never forget' included names such as Denison, Hughes, Bryce and Morris. Although the country had paid a great price to get to the postwar era, Shidehara found it disconcerting. His preference was for people who selflessly 'strived for the sake of the nation'. In this respect, he was very much of the prewar world. ${ }^{106}$

\section{Endnotes}

1 This chapter is based on my previous work: Hattori Ryūji, 'Shidehara Kijūrō to Sengo Seiji' [Shidehara Kijūrō and the postwar politics], Jinbunken Kiyō, no. 55 (October 2005): 1-37.

2 Asahi Shimbun, 15 August 1945; Matsumura Kenzō, Sandai Kaikoroku [A three-generation memoir] (Tokyo: Tōyō Keizai Shimpōsha, 1964), 245; 'Higashikuni-no-miya Nisshi', 23 August and 2 September 1945, Chūō/Sensō Shidō Jūyō Kokusaku Bunsho/1307; Satō Takumi, 'Kōfuku Kinenbi kara Shūsen Kinenbi e: Kioku no Media Event' [From the anniversary of surrender to the anniversary of the end of the war: Memory as a media event], in Sengo Nihon no Media Event: 1945-1960 Nen [Postwar Japan's media events: 1945-1960], ed. Tsuganesawa Toshihiro (Tokyo: Sekai Shisōsha, 2002), 71-93. It should also be noted that Higashikuni, Higashikuni Naruhiko Nikki, 221-28, is not the correct reprinting of 'Higashikuni-no-miya Nisshi'.

3 Studies of Shidehara of this period, which relate to this chapter as a whole, include Kunugi, 'Shidehara Kijūrō', 85-131; Iokibe Makoto, Senryō-ki: Shushō-tachi no Shin-Nihon [The age of occupation: The prime ministers' new Japan], (Tokyo: Yomiuri Shimbun, 1997), 106-226. These two works present sharply different interpretations. While the latter takes a favourable view of Shidehara, the former levels harsh criticism, stating:

The apologetic, passive policy for wartime responsibility adopted by the Shidehara cabinet eventually led to the failure of Shidehara's desire to rehabilitate the empire, with GHQ demanding the purging of public officials and the fundamental revision of the Japanese constitution (p. 115). 
As both these texts are written for the larger public, they do not contain a detailed analysis that goes beyond Shidehara's public statements to reflect the significance that Shidehara privately attached to the Survey Association of Greater East Asia War, and how he viewed the matter of war responsibility. Along these lines, in this chapter I will also examine disagreements between Shidehara and the Shōwa emperor, and his relationship with party politics.

On the topic of constitutional reform, while the focus has traditionally been on whether Shidehara was the initial proposer of Article 9, in this chapter I will draw on material such as interview records and historical documents related to the Constitution Research Council to trace the contours of Shidehara's own views on the constitution. I note that Shidehara was in favour of conducting constitutional reform, not only through the process of a general election but also through a national referendum. I also investigate his radio broadcasts.

4 Shidehara to Ōdaira, 25 August 1945, in 'Shidehara Heiwa Bunko', Reel 17. See also Shidehara Peace Foundation, Shidehara Kijürō, 546-48; Shidehara, Gaikō 50 Nen, 216-18.

Ōdaira was the former vice-president of the Manchurian Railway Company and became a member of the House of Peers in November 1945. On 19 March 1946, he became a privy councillor at the recommendation of Shidehara. See 'Nin Sūmitsu Komonkan Ōdaira Komatsuchi' [Appointing Ōdaira Komatsuchi to privy councillor], 19 March 1946, 1-2A-001-00-Betsu-00230-100, National Archives of Japan. For a brief history of Ōdaira’s life, see Hamuro Michiko, ed., Hinmin Kyügo Jigyō Shitashirabe [Investigation into projects to assist the needy] (Tokyo: Seitoku Memorial Welfare Office, 1989), 107. For details on Shidehara's selection as the chairman of the Japan Club in June 1946, see Japan Club, Nihon Club 100 Nen-shi [A hundred-year history of the Japan club] (Tokyo: Japan Club, 1999), 55.

5 'Shidehara Heiwa Bunko', Reels 7 and 17; Shidehara Peace Foundation, Shidehara Kijūrō, 548-51, 560.

6 Ōta et al., Tsugita Daisaburō Nikki, 34, 50-51, 193.

$7 \quad$ Kido Diary Research Association, Kido Köichi Nikki, vol. 2, 1240-41; Hosokawa, Hosokawa Nikki, vol. 2, 167-68; Kinoshita Michio, Sokkin Nisshi [Journal of an advisor] (Tokyo: Bungei Shunjū, 1990), 103-04.

8 Ōta et al., Tsugita Daisaburō Nikki, 35, 48. See also 'Higashikuni-no-miya Nisshi' 7 October 1945; Higashikuni, Higashikuni Naruhiko Nikki, 247; Kojima Kazuo, Ichi Rō-Seijika no Kaisō [The memories of an old politician] (Tokyo: Chūōkōronsha, 1975), 263-66; Itō Takashi and Watanabe Yukio, eds, Zoku Shigemitsu Mamoru Shuki [The notes of Shigemitsu Mamoru, continued] (Tokyo: Chuōkōronsha, 1988), 270; Asahi Shimbun, ed., Irie Sukemasa Nikki [The diary of Irie Sukemasa], vol. 2 (Tokyo: Asahi Shimbun, 1990), 13.

9 Shidehara, Gaikō 50 Nen, 214.

10 Ōta et al., Tsugita Daisaburō Nikki, 49.

11 'Kido Kōichi Seiji Danwa Rokuon Sokkiroku' [Shorthand record of a recording of a conversation with Kido Kōichi], vols 1-2, Modern Japanese Political History Materials Room, National Diet Library.

12 Shidehara Peace Foundation, Shidehara Kijūrō, 559-63.

13 Shindō Eiichi and Shimokōbe Motoharu, eds, Ashida Hitoshi Nikki [The diary of Ashida Hitoshi], vol. 1 (Tokyo: Iwanami Shoten, 1986), 50; Domestic Political History Research Association, ed., Horikiri Zenjirō-shi Danwa Dai 1 Kai Sokkiroku [First shorthand record of discussion with Mr Horikiri Zenjirō] (Tokyo: Domestic Political History Research Association, 1963), 29; Domestic Political History Research Association, ed., Horikiri Zenjirō-shi Danwa Dai 3 Kai Sokkiroku [Third shorthand record of discussion with Mr Horikiri Zenjirō] (Tokyo: Domestic Political History Research Association, 1964), 14-18; Taika Society History of the Ministry of Home Affairs Compilation Committee, ed., Naimu-shö-shi [History of the Ministry of Home Affairs], vol. 4 (Tokyo: Taika Society, 1971), 210-11; Narahashi Wataru, Gekiryū ni Saosashite [Punting through the rapids] (Tokyo: Tsubasa Soin, 1968), 43-45, 54-55; Shibusawa Keizō, Shibusawa Keizō Chosaku-shū [Selected works of Shibusawa Keizō], vol. 5 (Tokyo: Heibonsha, 1993), 405. 
14 Yoshida Shigeru Memorial Project Foundation, Yoshida Shigeru Shokan, 670; Izawa Takio Document Research Association, Izawa Takio Kankei Bunsho, 56; Ōnishi Hiroshi, 'Senchū Sengo no Izawa Takio: Naimu Kanryō Shihai no Shūen' [Izawa Takio during and after the war: The end of the dominance of the home affairs bureaucrats], in Izawa Takio to Kindai Nihon [Izawa Takio and modern Japan], ed. Ōnishi Hiroshi (Tokyo: Fuyō Shobō Shuppan, 2003), 210-15.

15 Office of the Chief of Counter Intelligence, GHQ, 'Biographical Notes on the Members of the Shidehara Cabinet', 23 October 1945, Record Group 331, Box 2044, National Archives.

16 Yoshida, Kaisō 10 Nen, vol. 1, 128.

17 Journal of Forbes, Forbes Papers, second series, vol. 5.

18 '10 Gatsu 11 Nichi Shidehara Shushō nitaishi Hyōmei-seru “MacArthur” Iken' [11 October, the declaration of the MacArthur opinion with regard to Prime Minister Shidehara], date unknown, in 'Rengō-gun no Hondo Shinchū narabini Gunsei Kankei Ikken: Rengō-gun-gawa to Nihon-gawa tono Renraku Kankei, Rengō-koku Saikō Shikan oyobi Bakuryō to Honpō Shushō narabini Kakushō Yōjin tono Kaidan Yoroku narabini Ōfuku Shokan Kankei' [Matter concerning the occupation of the homeland by allied forces and the establishment of a military government: Relating to communication between the allied forces and the Japanese side, abridged records of dialogue as well as correspondence between the supreme commander for the allied powers and staff officers, and the prime minister of Japan and leading figures of respective ministries], A'.1.0.0.2-3-4, reel A'-0055, Diplomatic Archives of the Ministry of Foreign Affairs of Japan; 'Sōri 'MacArthur' Kaidan Yōshi' [Summary of discussion between the prime minister and MacArthur], 13 October 1945, ibid.

See also '10 Gatsu 11 Nichi Sōri "MacArthur” Kaidan-go niokeru Rengō-gun Shirei-bu Shimbun Happyō (Kayaku)' [Newspaper announcement by the allied forces headquarters following the 11 October talks between the prime minister and MacArthur (provisional translation)], in 'Satō Tatsuo Kankei Bunsho' [Documents relating to Satō Tatsuo], Constitution Department, Reel 1, Modern Japanese Political History Materials Room, National Diet Library; Government Section, Supreme Commander for the Allied Powers, Political Reorientation of Japan, September 1945 to September 1948, vol. 2 (Westport: Greenwood Press, 1970), 741; Etō Jun, ed., Senryō Shiroku [Historical Records of the Occupation], comp. Hatano Sumio, vol. 2 (Tokyo: Kōdansha, 1995), 111-20; Ōta et al., Tsugita Daisaburō Nikki, 78-79; Shindō and Shimokōbe, Ashida Hitoshi Nikki, vol. 1, 52.

19 Ōta et al., Tsugita Daisaburō Nikki, 36, 81-83.

20 Kanpō, extra edition, 29 November 1945. The draft was by Tsugita. See Ōta et al., Tsugita Daisaburō Nikki, 137.

21 'Heiwa Jōyaku Mondai Kenkyū Kanji-kai no Ken' [Matter of the research board for the peace treaty problem], 21 November 1945, in 'Tai-Nichi Heiwa Jōyaku Kankei: Junbi Kenkyū Kankei' [Relating to the peace treaty with Japan: Relating to preparatory research], vol. 1, B'.4.0.0.1, Reel B'0008, Diplomatic Archives of the Ministry of Foreign Affairs of Japan. Also see Nishimura Kumao, 'San Francisco Heiwa Jōyaku nitsuite' [Regarding the San Francisco peace treaty], Kasumigaseki-kai Kaihō, no. 400 (May 1979): 24.

22 Shidehara cabinet meeting decision, 'Haisen no Genin oyobi Jissō Chōsa no Ken' [The matter of the investigation of the cause and true nature of the defeat], 30 October 1945, 1-2A-029-04-Shō 57 Sō -00128-100, National Archives of Japan; Shidehara cabinet meeting decision, 'Dai Tōa Sensō Chōsa-kai Kansei' [Governmental regulation on the survey association of Greater East Asia War], 29 November 1945, ibid.

23 Sensō Chōsa-kai Jimukyoku [The War Research Institute secretariat], 'Sensō Chōsa-kai Dai 1 Kai Sōkai niokeru Shidehara Sōsai no Aisatsu' [President Shidehara’s opening remarks for the War Research Institute's first general meeting], 27 March 1946, 1-2A-040-00-Shi-00306-100.

24 Aoki Tokuzō's comments within the subcommittee on the establishment of the new constitution, 10 July 1958, in Kenpo Seitei no Keika nikansuru Shouiinkai Dai 8 Kai Gijiroku [Proceedings of the eighth subcommittee meeting, relating to the establishment of the new constitution], ed. Constitution Research Council (Tokyo: Constitution Research Council, 1958), 2.

25 'Sensō Chōsa-kai Shiryō Tsuzuri' [The War Research Institute resource file], Bunko/Miyazaki Shūichi /95, Military Archives, Center for Military History, the National Institute for Defense Studies. 
26 'Kensei Shiryō-shitsu Shūshū Bunsho' [Collected documentation of the Constitutional Resource Center], no. 1244, Modern Japanese Political History Materials Room, National Diet Library; Aoki Tokuzō, 'Sensō Chōsa-kai no Hossoku kara Haishi made' [The War Research Institute, from its inception to its termination], date unknown, in 'Shidehara Heiwa Bunko', Reel 12; Domestic Political History Research Association, ed., Aoki Tokuzō-shi Danwa Sokkiroku [Shorthand record of a discussion with Mr Aoki Tokuzō] (Tokyo: Domestic Political History Research Association, 1964), 1-4, 10, 15, 24-25, 81-82; Ōta et al., Tsugita Daisaburō Nikki, 135.

27 Yoshida Yutaka, Nihonjin no Sensōkan [The Japanese view on war] (Tokyo: Iwanami Shoten, 1995), 29

28 Shidehara to Makino, 8 December 1945, in 'Makino Nobuaki Kankei Bunsho', Correspondence Department, vol. 28, 476-76.

29 Shindō and Shimokōbe, Ashida Hitoshi Nikki, vol. 1, 115-16, 262, 263, 265.

30 Journal of Miyazaki Shuichi, 17 August 1946, in 'Miyazaki Shūichi Chūjō Nisshi: Fukuin Jidai Nisshi, Ni' [The Journal of Lieutenant General Miyazaki Shūichi: Writings on the era of demobilization, 2], Chūō/Sakusen Shidō Nisshi/564, Military Archives, Center for Military History, the National Institute for Defense Studies; Aoki Tokuzō's comments within the subcommittee on the establishment of the new constitution, 10 July 1958, in Constitution Research Council, Kenpō Seitei no Keika nikansuru Shouiinkai Dai 8 Kai Gijiroku, 3.

31 Shidehara Kijūrō, 'Jo' [Introduction], in Aoki Tokuzō, Taiheiyō Sensō Zenshi [The prehistory of the Pacific War], vol. 1 (Tokyo: World Peace Construction Society, 1951), 1-5.

32 Kishi Kuramatsu, 'Shidehara-san to Konoe Kō Den' [Mr Shidehara and the biography of Lord Konoe], date unknown, in 'Shidehara Heiwa Bunko', Reel 13.

33 Shidehara cabinet meeting decision, 'Rikukaigun-shō no Haishi nikansuru Ken' [Abolishing the Ministry of War and Ministry of Navy], 26 October 1945, 1-2A-029-04-Shō 57 Sō-00128-100, National Archives of Japan.

34 Contents of Prime Minister Shidehara's broadcast, 'Fukuin Gunjin nitsuite' [regarding demobilised soldiers], 7 February 1946, 1-2A-040-00-shi-00306-100, National Archives of Japan. See also 'Shidehara Heiwa Bunko', Reel 12.

35 Narahashi Wataru's discourse, date unknown, in 'Shidehara Heiwa Bunko', Reel 13; Narahashi's discourse, 22 October 1954, in 'Nihon-koku Kenpō Seitei nikansuru Danwa Rokuon' [Recording of conversations regarding the establishment of Japan's constitution], no. 1, Modern Japanese Political History Materials Room, National Diet Library. Narahashi, Gekiryū ni Saosashite, 55-64; Japanese Communist Party Central Committee, Zōhöban Nihon Kyōsantō no 50 Nen [Fifty years of the Japanese Communist Party], 2nd ed. (Tokyo: Japanese Communist Party Central Committee Press, 1977), 101-04; Biography of Narahashi Wataru Editing Committee, Narahashi Wataru Den [Biography of Narahashi Wataru] (Tokyo: Biography of Narahashi Wataru Publishing Association, 1982), 110-15.

36 Yamagiwa Akira and Nakamura Masanori, eds, Shiryō Nihon Senryō, vol. 1: Tennōsei [Documents on Japan's occupation, vol. 1: The emperor system], trans. Ryōnosuke Okada (Tokyo: Ōtsuki Shoten, 1990), 404, 411-13, 414-16, 454-55, 463-64. See also Masumi Junnosuke, Shōwa Tennō to Sono Jidai [The Shōwa emperor and his era] (Tokyo: Yamakawa Shuppansha, 1998), 45-48, 63-64.

37 Kido Diary Research Association, ed. Kido Köichi Kankei Bunsho [Documents relating to Kido Kōichi] (Tokyo: University of Tokyo Press, 1966), 512-14. Toyoshita Narahiko, 'Tennō ha Nani wo Katattaka: "Tennō, MacArthur Kaiken” no Rekishi-teki Ichi' [What did the emperor say? The historical significance of the emperor-MacArthur meeting] (1), Sekai, no. 537 (February 1990): 234-36; Shibata Shinichi, 'Dai 1 Kai Shōwa Tennō-MacArthur Kaiken to Yoshida Shigeru' [The first Shōwa emperor-MacArthur meeting and Yoshida Shigeru], Kokugakuin Daigaku Nihon Bunka Kenkyū-jo Kiyo, no. 82 (September 1998): 98-106.

38 New York Times, 25 September 1945; Matsuo Takayoshi, Sengo Nihon eno Shuppatsu [Embarking on postwar Japan] (Tokyo: Iwanami Shoten, 2002), 101.

39 'Shikibushoku: Ekken-roku' [Board of the ceremonies: Record of audience with the emperor], 1945, Imperial Household Archives. 
40 Kido Diary Research Association, Kido Köichi Nikki, vol. 2, 1237; Shidehara to Ōdaira, 29 September 1945, in 'Shidehara Heiwa Bunko', Reel 17; Asahi Shimbun, Irie Sukemasa Nikki, vol. 2, 10-11; Asahi Shimbun, 27 July 2006.

41 Okumura Katsuzō, “"MacArthur” Gensui tono Go-Kaiken-roku' [Record of a meeting with General MacArthur], 27 September 1945, in 'Shōwa Tennō to Rengō-koku Saikō Shireikan MacArthur Gensui no Kaidan-roku (1945 Nen 9 Gatsu 27 Nichi)' [Record of meeting between the Shōwa emperor and General MacArthur, supreme commander of the allied powers (27 September 1945)], 01-385, Diplomatic Archives of the Ministry of Foreign Affairs of Japan. The same meeting record also appears in 'Gaikō Zatsuroku: Shikibushoku' [Miscellaneous diplomatic records: Board of the ceremonies], 1945, Imperial Household Archives. Also see Asahi Shimbun, evening edition, 17, 24 October 2002.

Further, according to MacArthur's own memoirs, the emperor stated, 'I take full responsibility'. See Douglas MacArthur, Reminiscences (New York: McGraw-Hill Book Company, 1964), 288. There is no entry of this nature in the reference: Okumura Katsuzō, "MacArthur" Gensui tono Go-Kaiken-roku'. However, according to Matsui Akira's documents, with respect to the statement 'by the Emperor that he took full responsibility for the war', Okumura 'deleted this from the record out of consideration of its enormous importance'. For this reason, it seems highly possible that the relevant entry was removed. See Asahi Shimbun, 5 August 2002; Toyoshita Narahiko, 'Shōwa TennōMacArthur Kaiken wo Kenshō Suru: "Matsui Bunsho" wo Yomitoku' [Examining the meeting between the Shōwa emperor and MacArthur: Close reading and analysis of the 'Matsui documents'] (1), Ronza, no. 90 (November 2002): 60-61.

42 Terasaki Hidenari, “"MacArthur Gensui” tono Go-Kaiken-roku' [Record of a meeting with General MacArthur], 16 October 1946, in 'Shidehara Heiwa Bunko', Reel 3. This is a record of the third meeting between the Emperor and MacArthur, and it was written using the ruled paper of the Ministry of the Imperial Household. This meeting is discussed in Naganuma Setsuo, 'HatsuKōkai Sareta "Tennō-MacArthur" Dai 3 Kai Kaiken no Zenyō' [The full story of the third 'emperorMacArthur' meeting, now public for the first time], Asabi Journal 31, no. 10 (March 1989): 26-30.

Considering the historical material of the above reference, over time, in his meetings with MacArthur, the emperor became more pronounced in making political statements, such as criticising the strikes at the time or speaking about the threat of communism. Such behavior exceeded the purely ceremonial role of the emperor by the newly established constitution. MacArthur also sought to draw out the emperor's opinions. This sheds light on MacArthur's own attitude with respect to the new constitution.

43 Ministry of Foreign Affairs Treaties and Conventions Bureau, 'Kaisen no Sekinin to Kokunaihō-jō niokeru Tennō no Go Chii' [Responsibility for the commencement of the war, and the position of the emperor with respect to domestic law], date unknown, in 'Honpō Sensō Hanzainin Kankei Zakken: Chosa Shiryo Kankei (Shimbun, Kirinuki wo Fukumu)' [Miscellaneous cases concerning Japanese war criminals: Relating to investigation documents (including newspaper cuttings)], vol. 1, D’1.3.0.1-13, Diplomatic Archives of the Ministry of Foreign Affairs of Japan.

44 Awaya Kentarō, ed., Shiryo, Nihon Gendai-shi [Resources, modern Japanese history], vol. 2 (Tokyo: Ōtsuki Shoten, 1980), 341-43. See also Awaya Kentarō, Tōkyō Saiban-ron [Discourse on the Tokyo trial] (Tokyo: Ōtsuki Shoten, 1989), 69; Awaya Kentar., Gendai-shi Hakkutsu [Excavating modern history] (Tokyo: Ōtsuki Shoten, 1996), 152-53. However, according to Higurashi Yoshinobu, it was not decided by the cabinet but indeterminate. See Higurashi Yoshinobu, Toyko Saiban no Kokusai Kankei: Kokusai Seiji niokeru Kenryoku to Kihan [The Tokyo trial's international relations: Power and standards in international politics] (Tokyo: Bokutakusha, 2002), 310.

I also note that in the document 'Sensō Sekinin nikansuru Ken' [Matter concerning responsibility for the war], date unknown, which was written on lined paper that was standard for the Japanese army, there are statements concerning the emperor:

With respect to the decision to begin the war, and matters such as the carrying out of strategy planning, etc., what the supreme command staff and the government decided upon had to conform to the working precedence of the constitution; these decisions were not rejected.

See 'Fukuin-sho Kaneki Shiryo' [Documents relating to the Ministry for Demobilization], 12-5, Modern Japanese Political History Materials Room, National Diet Library. 
45 Ōta et al., Tsugita Daisaburō Nikki, 118-19. Fellers saw the emperor as the living symbol of the race'. See Fellers to the Commander-in-Chief, 2 October 1945, Bonner F. Fellers Papers, Box 3, Hoover Institution, Stanford University. For further information on Fellers, see Iguchi Haruo, 'Sengo Nihon no Kunshu-sei to America' [Postwar Japan's monarchy and the US], in 20 Seiki Nihon no Tenno to Kunshusei: Kokusai Hikaku no Shiten kara, 1867-1947 [20th-century Japan's emperor system and monarchy: From the perspective of an international comparison, 1867-1947], ed. Itō Yukio and Kawada Minoru (Tokyo: Yoshikawa Kōbunkan, 2004), 129-55.

46 Conversation with Narahashi Wataru, 22 October 1954, in 'Nihon-koku Kenpō Seitei nikansuru Danwa Rokuon', no. 1; Ishiwata Sōtarō Biography Compilation Society, ed., Ishiwata Sōtarō [Ishiwata Sōtarō] (Tokyo: Ishiwata Sōtarō Biography Compilation Society, 1954), 485; Yamanashi Katsunoshin Memorial Publishing Committee, ed., Yamanashi Katsunoshin Sensei Ihō-roku [In remembrance of Mr Yamanashi Katsunoshin] (Tokyo: Yamanashi Katsunoshin Memorial Publishing Committee, 1968), 315-17; William P. Woodard, The Allied Occupation of Japan 1945-1952 and Japanese Religions (Leiden: E. J. Brill, 1972), 252-68; Togashi Junji, Tennō totomoni Gojū-nen [Fifty years with the emperor] (Tokyo: Asahi Shimbun, 1977), 98-112; Shishikui Seiichi, ed., Shin Jo Sui: Ishiwata-san wo Shinobu [A heart like water: Remembering Ishiwata-san] (Tokyo: Tokyo Post, 1982), 267-74; Kawashima Yasuyoshi, ed., Kaisō no Blyth [Our memories of Blyth] (Tokyo: Memories of Blyth Publishing Association Office, 1984), 161-66; Takahashi Hiroshi and Suzuki Kunihiko, Tenno-ke no Misshi-tachi: Senryō to Köshitsu [The confidential agents of the imperial household: The occupation and the imperial family] (Tokyo: Bungei Shunjū, 1989), 72-92; Hirakawa Sukehiro, Heiwa no Umi to Tatakai no Umi [Sea of peace, sea of war] (Tokyo: Kōdansha, 1993), 240-91; Adrian Pinnington, 'R. H. Blyth, 1898-1964', in Britain and Japan: Biographical Portraits, ed. Ian Nish (London: Routledge Curzon, 1994), 259-60; Masumi, Shōwa Tennō to Sono Jidai, 56-59.

47 Declaration of Humanity, English Draft, 15-20 December 1945, in 'Yamanashi Katsunoshin Bunsho' [Documents of Yamanashi Katsunoshin], A 1 Appendix, Gakushūin University Historical Document Room; 'Shōsho no Anbun Sakusei, Kanpatsu made no Tejun oyobi Ryūiten-to nikansuru Kyōgi Memo' [Conference notes relating to the procedure and points for consideration, etc., relating to the drafting and promulgation of the imperial rescript], date unknown, in 'Yamanashi Katsunoshin Bunsho', A4 Appendix. However, the author of the notes in the 'Yamanashi Katsunoshin Documents' is not stated. See also Kinoshita, Sokkin Nisshi, 336-40; Asahi Shimbun, 1, 4 January 2006.

48 Declaration of Humanity, English Draft, 15-20 December 1945; 'Shōsho no Anbun Sakusei, Kanpatsu made no Tejun oyobi Ryūiten-to nikansuru Kyōgi Memo’.

49 Maeda Tamon, 'Ningen Sengen no Uchisoto' [The public and private aspects of the 'Declaration of Humanity'], Bungei Shunjü 40, no. 3 (March 1962), 84-90; Kinoshita, Sokkin Nisshi, 84, 86, 89-96. According to this Kinoshita journal, Yoshida Shigeru was also involved in formulating the Declaration of Humanity. According to Sodei Rinjirō, Yoshida sent the translated version of the declaration to MacArthur. See Sodei Rinjirō, ed., Yoshida-MacArthur Öfuku Shokanshū, 1945-1951 [YoshidaMacArthur correspondence collection, 1945-1951] (Tokyo: Hōsei University Press, 2000), 119-20.

However, for some reason, Yoshida stated in a discussion that he was not a party to the circumstances of the Declaration of Humanity. See conversation with Yoshida Shigeru, 5 October 1955, in 'Nihonkoku Kenpō Seitei nikansuru Danwa Rokuon', no. 8.

50 Asahi Shimbun, 1 January 1946.

51 Togashi Junji, Heika no 'Ningen' Sengen [The Declaration of Humanity of his highness] (Tokyo: Dōwa Shobō, 1946), 6-7.

In Prince Takamatsu, Takamatsu-no-miya Nikki, vol. 8, 287, an entry states:

The promulgation of the Imperial Rescript was extremely well executed. However, I wished that we could have used an alternative to the three-character word 'Akitsumikami' [現御 神, living God], replacing it with simply the character for 'Kami' [God, 神] instead. Prime Minister Shidehara showed the English-language manuscript to 'Mac,' and then this was turned back into Japanese. So, while the Board of Chamberlains made some revisions, it ended up being put out in a form that was fairly different from the original.

52 Asahi Shimbun, 24 August 1977. 
53 Fujita Hisanori, Jijūchō no Kaiso [Recollections of the grand chamberlain of the emperor] (Tokyo: Chūōkōronsha, 1987), 217; Kinoshita, Sokkin Nisshi, 54-126. See also 'Kansai Gyōkō nikansuru Shidehara Naikaku Sōri Daijin Kinwa' [Prime Minister Shidehara’s respectful comments relating to the emperor's visit to the Kansai region], 21 November 1945, 1-2A-040-00-shi-00306-100, National Archives of Japan.

54 Ministry of Foreign Affairs Public Information and Cultural Affairs Bureau, eds, Korekara no Nihon no Gaikō: Ōhira Gaimu Daijin ni Kiku [Japanese diplomacy going forward: Listening to Foreign Minister Ōhira] (Tokyo: Ministry of Foreign Affairs, 1973), 13.

55 Matsumura, Sandai Kaikoroku, 271-75.

56 Shindō and Shimokōbe, Ashida Hitoshi Nikki, vol. 1, 63-66, 237; Fukunaga Fumio, Senryōka Chüdō Seiken no Keisei to Hōkai [The formation and disintegration of the centrist government under the occupation] (Tokyo: Iwanami Shoten, 1997), 52.

57 Kido Diary Research Association, Kido Köichi Nikki, vol. 2, 1241; 'Kido Kōichi Seiji Danwa Rokuon Sokkiroku', vol. 2. Also see Shigemitsu Mamoru, Sugamo Nikki [Sugamo diary] (Tokyo: Bungei Shunjū Shinsha, 1953), 374; Itō Takashi and Watanabe Yukio, eds, Shigemitsu Mamoru Shuki [The notes of Shigemitsu Mamoru] (Tokyo: Chuōkōronsha, 1986), 575; Itō and Watanabe, Zoku Shigemitsu Mamoru Shuki, 271. For more recent research on the history of the establishment of Japan's constitution, see Nishi Osamu, Nihon-koku Kenpō Seiritsu Katei no Kenkyū [A study of the establishment of the Japanese constitution] (Tokyo: Seibundō, 2004).

58 Etō, Senryō Shiroku, 123-27.

59 The first general meeting of the Constitutional Problems Investigation Committee, 27 October 1945, in 'Satō Tatsuo Kankei Bunsho', Constitution Department, Reel 1. For the minutes of the Constitutional Problems Investigation Committee, see Ashibe Nobuyoshi, Takahashi Kazuyuki, Takami Katsutoshi and Hibino Tsutomu, eds, Nihon Kenpō Seitei Shiryō Zenshū I: Kenpō Mondai Chōsa Iinkai Kankeki Shiryō-tō [A complete collection of documents relating to the establishment of the Japanese constitution-I: Documents, etc., relating to the Constitutional Problems Investigation Committee] (Tokyo: Shinzansha, 1997), 319-400.

Also see Satō Tatsuo, Nihon-koku Kenpō Seiritsu-shi [A history of the establishment of the Japanese constitution], vol. 1 (Tokyo: Yūhikaku, 1962), 252; Ōta et al., Tsugita Daisaburō Nikki, 87-88; Yoshida Shigeru Memorial Project Foundation, Yoshida Shigeru Shokan, 671; Itō, Takagi Sōkichi Nikki to Jōhō, vol. 2, 963.

60 Kanpō, extra edition, 29 November 1945.

61 George Sansom diary, 22 January 1946, F 3595/2/23, FO 371/54086, National Archives. See also Katharine Sansom, Sir George Sansom and Japan: A Memoir (Tallahassee: Diplomatic Press, 1972), 151.

62 Kenpō Chōsa-kai Jimukyoku [Office of the Constitution Research Council], 'Sensō Hōki Jōkō to Tennō-sei Iji tono Kanren nitsuite: Ōdaira Komatsuchi-shi no Sokujo no Memo' [On the relation of the war waiver clause and the retention of the emperor system: Notes by the daughter of $\mathrm{Mr}$ Odaira Komatsuchi], February 1959, 1-2A-038-08-ken-00115-105, National Archives of Japan. The same historical material is also available in 'Satō Tatsuo Kankei Bunsho', Constitution Department, Reel 60; 'Kenpō Chōsa-kai Shiryō' [Constitution Research Council material], Reel 20, Modern Japanese Political History Materials Room, National Diet Library. There is also a section included in Ōtake Hideo, ed., Sengo Nihon Böei Mondai Shiryōshü [Postwar Japan defence issues sourcebook], vol. 1 (Tokyo: Sanichi Shobō, 1991), 66-67; Government Periodical Contents Publication Association, Kenpō Chösa-kai Shiryō Mokuji Söran [Contents overview of resources relating to the Constitution Research Council], vol. 3 (Tokyo: Bunka Tosho, 2002), 304.

Also see conversation with Narahashi Wataru, 22 October 1954, in 'Nihon-koku Kenpō Seitei nikansuru Danwa Rokuon', no. 1; conversation with Yoshida Shigeru, 5 October 1955, ibid., no. 8; Yoshida, Kaiso 10 Nen, vol. 4, 178; Office of the Constitution Research Council, ed., Kenpo Seitei no Keika nikansuru Shöiinkai Hōkokusho [Subcommittee report on the process of establishing the constitution] (Tokyo: Ministry of Finance Printing Bureau, 1961), 323-38; Hata Ikuhito, Shiroku: Nihon Saigunbi [Historical records: The rearmament of Japan] (Tokyo: Bungei Shunjū, 1976), 58-67; Tanaka Hideo, 
Kenpō Seitei Katei Oboegaki [Memorandum on the process of establishing the constitution] (Tokyo: Yūhikaku, 1979), 90-100; Aoki Kazuo, Waga 90 Nen no Shögai wo Kaerimite [Looking back on my 90 years] (Tokyo: Kōdansha, 1981), 281-92; Satō Tatsuo, Nihon-koku Kenpō Tanjō-ki [Record of the birth of the Japanese constitution] (Tokyo: Chūō Kōron Shinsha, 1999), 78, 92-93.

63 Kenpō Chōsa-kai Jimukyoku, 'Sensō Hōki Jōkō to Tennō-sei Iji tono Kanren nitsuite'.

64 Shiratori to Yoshida (English), 10 December 1945, in 'Kyokutō Kokusai Gunji Saiban Shiryō' [Documents on the International Military Tribunal for the Far East], D2919, Box 192, Modern Japanese Political History Materials Room, National Diet Library. For the Japanese-language text, see D2919, Box 57. See also Asahi Shimbun, 14 October 2005.

65 Affidavit of Yoshida Shigeru (English), 4 December 1947, in 'Kyokutō Kokusai Gunji Saiban Shiryō', D2920, Box 192, Modern Japanese Political History Materials Room, National Diet Library. For the Japanese-language version, see D2920, Box 17.

According to Kanamori Tokujirō:

Shiratori apparently submitted a petition to MacArthur and Shidehara to the effect that war had to be renounced. I think this is probably true ... Actually, Mr. Kishi [Shidehara's secretary, Kishi Kuramatsu] himself also said that he saw the petition being submitted to Shidehara.

See conversation with Kanamori Tokujirō, 16 December 1957, in 'Nihon-koku Kenpō Seitei nikansuru Danwa Rokuon', vol. 9. Kanamori was a member of the House of Peers and served as the minister of state in the first Yoshida cabinet.

66 Hirota Yōji, “'Senpan” Shiratori Toshio to Kenpō Dai Kyū-jō’ ['War criminal' Shiratori Toshio and Article 9 of the constitution], Nihon Shühö, no. 374 (July 1956): 43-47. The same manuscript is also included in Hirota Yōji, 'Kenpō Dai-Kyū-jō wa Dare ga Tsukutta ka' [Who created Article 9 of the constitution?], Nihon Shühō, no. 525 (December 1960): 78-83.

67 Hirota, “'Senpan” Shiratori Toshio to Kenpō Dai Kyū-jō’, 43-47.

68 Shigemitsu, Sugamo Nikki, 109; Tobe Ryōichi, 'Shiratori Toshio to Manshū Jihen' [Shiratori Toshio and the Manchurian Incident], Bōei Daigakkō Kiyō, no. 39 (September 1979): 83; Higurashi, Tokyo Saiban no Kokusai Kankei, 375.

69 Satō Tatsuo, Nihon-koku Kenpō Seiritsu-shi, vol. 2 (Tokyo: Yūhikaku, 1964), 631-34. Irie Toshio, Kenpō Seiritsu no Keii to Kenpō-jō no Sho-Mondai: Irie Toshio Ronshū [The circumstances surrounding the establishment of the constitution, and the various constitutional problems: Irie Toshio essay collection] (Tokyo: Irie Toshio Essay Collection Publishing Committee, 1976), 69-81, 96-107, 201-03.

70 Interview of Shidehara by the National Catholic Welfare Conference News Service (Father Patrick O’Connor, correspondent), 31 January 1946, in 'Shidehara Heiwa Bunko', Reel 17.

71 Mainichi Shimbun, 1 February 1946. Also see Tanaka, Kenpō Seitei Katei Oboegaki, 39-49.

72 Mainichi Shimbun, 3 May 1997. See also Hosokawa, Hosokawa Nikki, vol. 2, 173-74; Iokibe, Senryō-ki, 205-08.

73 Mainichi Shimbun, 3 May 1997.

74 Charles L. Kades oral history, 12 December 1961, Oral History Research Office, Columbia University; Takayanagi Kenzō, Ōtomo Ichirō and Tanaka Hideo, eds, Nihon-koku Kenpō Seitei no Katei, 1, Genbun to Honyaku: Rengo-koku So-Shireibu-gawa no Kiroku niyoru [The process of the establishment of the constitution of Japan, 1, the original and the translation: According to the records of the general headquarters of the allied powers] (Tokyo: Yūhikaku, 1972), 98-107.

75 Satō, Nihon-koku Kenpō Seiritsu-shi, vol. 2, 689-91.

76 Etō, Senryō Shiroku, vol. 2, 185-91; Takayanagi, Ōtomo and Tanaka, Nihon-koku Kenpō Seitei no Katei, 1, Genbun to Honyaku, 352-71; Satō Tatsuo, Nihon-koku Kenpō Seiritsu-shi, rev. Satō Isao, vol. 3 (Tokyo: Yūhikaku, 1994), 47-58.

77 Shindō and Shimokōbe, Ashida Hitoshi Nikki, vol. 1, 75-79. See also Kinoshita, Sokkin Nisshi, 155-56; Matsumura, Sandai Kaikoroku, 289-90.

78 Shindō and Shimokōbe, Ashida Hitoshi Nikki, vol. 1, 79-80. 
79 Ibid., 80.

80 Comment by Ashida Hitoshi at the Constitution Research Council general meeting, 5 December 1957, in Kenpō Chōsa-kai Dai 7 Sökai Gijiroku [Minutes of the seventh general meeting of the Constitution Research Council], ed. Constitution Research Council (Tokyo: Constitution Research Council, 1957), 76; Takayanagi Kenzō, Ōtomo Ichirō and Tanaka Hideo, eds, Nihon-koku Kenpō Seitei no Katei, 2, Kaisetsu: Rengo-koku So-Shireibu-gawa no Kiroku niyoru [The process of the establishment of the constitution of Japan, 2, commentary: according to the records of the general headquarters of the allied powers] (Tokyo: Yūhikaku, 1972), 84.

81 Respectful comment draft by Shidehara, 6 March 1946, in 'Shidehara Heiwa Bunko', Reel 2. Also see respectful comment by Shidehara, $6 \mathrm{March}$, in 'Irie Toshio Kankei Bunsho' [Documents relating to Irie Toshio], Reel 7, Modern Japanese Political History Materials Room, National Diet Library; conversation with Satō Tatsuo, 28 February and 20 April 1955, in 'Nihon-koku Kenpō Seitei nikansuru Danwa Rokuon', no. 5; Asahi Shimbun, 7 March 1946; Satō, Nihon-koku Kenpō Seiritsushi, vol. 3, 74-75, 93, 111, 164, 177, 189, 200; Matsumura, Sandai Kaikoroku, 288, 291. The word shiko (superiority) was removed during the creation of the new constitution.

82 Yomiuri Hōchi, 27 February 1946.

83 Shindō and Shimokōbe, Ashida Hitoshi Nikki, vol. 1, 87-91; Kinoshita, Sokkin Nisshi, 163-65; Masumi, Shōwa Tennō to Sono Jidai, 67-70.

84 '21 Nen 3 Gatsu 20 Nichi Sūmitsuin niokeru Shidehara Sōridaijin no Kenpō Sōan nikansuru Setsumei Yoshi' [Summary of the explanation of the constitution draft as given by Prime Minister Shidehara at the Privy Council on 20 March of the 21st (Shōwa) year], in 'Shidehara Heiwa Bunko', Reel 3; Murakawa Ichirō, ed., Teikoku Kenpo Kaisei-an Gijiroku [Minutes of a meeting to draft a revised imperial constitution] (Tokyo: Kokusho Kankō-kai, 1986), 13-40.

85 'Teikoku Kenpō Kaisei nitsuki, Naikaku Sōri Daijin Setsumei Yōshi' [Outline of prime minister's explanation regarding the revision of the imperial constitution], 22 April 1946, in 'Suzuki Kantarō Kankei Bunsho' [Documents relating to Suzuki Kantarō], no. 13, Modern Japanese Political History Materials Room, National Diet Library; Sakurai Ryōjū, 'Suzuki Kantarō Nikki (Shōwa 21 Nen) nitsuite' [Regarding the diary of Suzuki Kantarō (Shōwa 21)], Noda-shi-shi Kenkyū, no. 16 (March 2005): 16, 24, 25.

86 Irie Toshio, Kenpō Seiritsu no Keii to Kenpō-jō no Sho-Mondai, 21; comment by Aoki Tokuzō at the subcommittee on the process of the establishment of a new constitution, 10 July 1958, in Constitution Research Council, Kenpō Seitei no Keika nikansuru Shouiinkai Dai 8 Kai Gijiroku, 3-4.

87 Conversation with Kanamori Tokujirō, 16 December 1957, in 'Nihon-koku Kenpō Seitei nikansuru Danwa Rokuon', no. 9; Terasaki, “"MacArthur Gensui” tono Go-Kaiken-roku'. Kanamori served positions such as the minister of state in the first Yoshida cabinet.

88 Mark Gayn, Japan Diary (New York: William Sloane Associates, 1948), 164-71; Izawa Takio Document Research Association, Izawa Takio Kankei Bunsho, 270.

89 Society for the Study of Parliamentary Government, Seitō Nenkan: Shōwa 22 Nen [Political party yearbook: Shōwa 22] (Tokyo: News Co., 1947), 37.

90 Shidehara Kijūrō, 'Konkai no Sōsenkyo nitsuite' [On this general election]', broadcast 9 April 1946, 1-2A-040-00-shi-00306-100, National Archives of Japan. See also 'Shidehara Heiwa Bunko', Reel 11.

91 Society for the Study of Parliamentary Government, Seitō Nenkan, 37-41; Kojima, Ichi RōSeijika no Kaisō, 266-269; Saitō Takao, Kaiko 70 Nen [Reflecting on 70 years] (Tokyo: Chūōkōronsha, 1987), 206-07.

See also Fukunaga, Senryōka Chūdō Seiken no Keisei to Hōkai, 70-74; Nakakita Kōji, Keizai Fukkō to Sengo Seiji: Nihon Shakaitō, 1945-1951 Nen [The economic recovery and postwar politics: The Socialist Party of Japan, 1945-1951] (Tokyo: University of Tokyo Press, 1998), 13-16.

92 Itō Takashi and Watanabe Yukio, eds, 'Saitō Takao Nikki (Shō)' [The diary of Saitō Takao (extract)], Chuōkōron 106, no. 1 (January 1991): 147-63. See also Narahashi, Gekiryū ni Saosashite, 135; Itō, Shōwa-ki no Seiji, 219-29, 273-74; Itō, Zoku Shōwa-ki no Seiji, 121. 
93 Sodei, Yoshida-MacArthur Öfuku Shokanshū, 1945-1951, 4-5, 121-23; Yoshida Shigeru Memorial Project Foundation, Yoshida Shigeru Shokan, 672; Hosokawa, Hosokawa Nikki, vol. 2, 197, 199; Itō Takashi and Suetake Yoshiya, eds, Hatoyama Ichirō, Kaoru Nikki [The diaries of Hatoyama Ichirō and Kaoru], vol. 1 (Tokyo: Chūō Kōron Shinsha, 1999), 437-40, 443.

94 Asahi Shimbun, Irie Sukemasa Nikki, vol. 2, 58; Ishibashi Tanzan, Ishibashi Tanzan Nikki: Shōwa 20-31 Nen [The diary of Tanzan Ishibashi: Shōwa 20-31], ed. Itō Takashi, vol. 1 (Tokyo: Misuzu Shobō, 2001), 115.

95 Society for the Study of Parliamentary Government, Seitō Nenkan, 40-42, 145-56.

For records of deliberations on revising the constitution, see Office of the Constitution Research Council, ed., Teikoku Kenpō Kaisei Shingi-roku [Records on deliberation concerning the revision of the imperial constitution], vol. 3 (Tokyo: Office of the Constitution Research Council, 1959), 16-17; ibid., vol. 4, 72-74, 189-190, 385; ibid., vol. 5, 287-89, 320-22, 394-95, 452-53, 459-62. See also Shimizu Shin, ed., Chikujō Nihon-koku Kenpō Shingi-roku [Records on article-by-article deliberation on the Japanese constitution], vol. 1 (Tokyo: Yūhikaku, 1962), 508-09, 519-20; ibid., vol. 2, 21-22; Maruyama and Fukuda, Kikigaki, 333.

96 Ashida to Shidehara, 19 April, 'Ashida Hitoshi Kankei Bunsho' [Documents relating to Ashida Hitoshi], Document Department, no. 165-2, Modern Japanese Political History Materials Room, National Diet Library.

97 Ashida to Shidehara, 'Jishokunegai' [Letter of resignation], 19 April 1946, in 'Ashida Hitoshi Kankei Bunsho', Document Department, no. 165-1.

98 Shindō and Shimokōbe, Ashida Hitoshi Nikki, vol. 1, 98-101, 138-40.

99 Ibid., 148.

100 Shidehara to Izawa, 2 June 1947, in Izawa Takio Document Research Association, Izawa Takio Kankei Bunsho, 271-72. See also Shindō and Shimokōbe, Ashida Hitoshi Nikki, vol. 1, 149, 152, 158, 161-62, 165, 167, 173, 181, 183, 184, 189, 193, 194, 197, 198, 199, 200, 324, 325, 326; Sugawara Tsūsai, 'Ashida Minshutō Sōsai no Kettei Made' [Until the selection of Ashida as president of the Democratic Party of Japan], 14 September, year unknown, in 'Shidehara Heiwa Bunko', Reel 13; Ishibashi, Ishibashi Tanzan Nikki, vol 1., 164, 191; Asahi Shimbun Political Party Press Corp, Seitō Nenkan: Shōwa 23 Nen [The political party yearbook: Shōwa 23] (Tokyo: News Co., 1948), 30-53, 79-90, 206-23.

101 A conversation with Ashida Hitoshi, 7 September, year unknown, in 'Shidehara Heiwa Bunko', Reel 4; Shindō and Shimokōbe, Ashida Hitoshi Nikki, vol. 2, 10-11.

102 Shidehara to Ishibashi Tanzan, 1 January 1948, in 'Ishibashi Tanzan Kankei Bunsho' [Documents relating to Ishibashi Tanzan], no. 292, Modern Japanese Political History Materials Room, National Diet Library.

103 Ishibashi Tanzan, 'Shidehara-san no Omoide' [Memories of Mr Shidehara], 1, Töyō Keizai Shinpō, no. 2465 (March 1951): 21.

104 Asahi Shimbun, 16, 29 November 1947 and 16 March 1948; Asahi Shimbun Political Party Press Corp, Seitō Nenkan: Shōwa 24 Nen [The political party yearbook: Shōwa 24] (Tokyo: News Co., 1949), 130-46; National Graduate Institute for Policy Studies, ed., Oral History Matsuno Raizō [Oral history Matsuno Raizō], vol. 1 (Tokyo: National Graduate Institute for Policy Studies, 2003), 50-51. For details on the movements of the Shidehara clique, see Fukunaga, Senryöka Chüdö Seiken no Keisei to Hökai, 190, 198-200, 216, 245, 270, 272.

105 Shidehara, Gaikō 50 Nen, 148-49.

106 Shidehara, 'Wasureenu Hitobito', 54-61. 
This text is taken from Japan at War and Peace: Shidehara Kijürō and the Making of Modern Diplomacy, by Ryuji Hattori, published 2021 by ANU Press, The Australian National University, Canberra, Australia.

doi.org/10.22459/JWP.2021.07 